\title{
First long-term and near real-time measurement of trace elements in China's urban atmosphere: temporal variability, source apportionment and precipitation effect
}

\author{
Yunhua Chang ${ }^{1,2,3}$, Kan Huang ${ }^{4}$, Mingjie Xie ${ }^{5}$, Congrui Deng ${ }^{4}$, Zhong Zou ${ }^{4,6}$, Shoudong Liu ${ }^{1,2,3}$, and \\ Yanlin Zhang ${ }^{1,2,3}$ \\ ${ }^{1}$ Yale-NUIST Center on Atmospheric Environment, International Joint Laboratory on Climate and Environment Change \\ (ILCEC), Nanjing University of Information Science \& Technology, Nanjing 210044, China \\ ${ }^{2}$ Key Laboratory of Meteorological Disaster, Ministry of Education (KLME)/ Collaborative Innovation Center on \\ Forecast and Evaluation of Meteorological Disasters (CIC-FEMD), Nanjing University of Information \\ Science \& Technology, Nanjing 210044, China \\ ${ }^{3}$ Jiangsu Provincial Key Laboratory of Agricultural Meteorology, College of Applied Meteorology, \\ Nanjing University of Information Science \& Technology, Nanjing 210044, China \\ ${ }^{4}$ Center for Atmospheric Chemistry Study, Shanghai Key Laboratory of Atmospheric Particle Pollution and Prevention \\ $\left(\mathrm{LAP}^{3}\right)$, Department of Environmental Science and Engineering, Fudan University, Shanghai 200433, China \\ ${ }^{5}$ School of Environmental Science and Engineering, Nanjing University of Information \\ Science \& Technology, Nanjing 210044, China \\ ${ }^{6}$ Pudong New Area Environmental Monitoring Station, Shanghai 200135, China
}

Correspondence: Yanlin Zhang (dryanlinzhang@outlook.com, zhangyanlin@ nuist.edu.cn)

Received: 30 June 2017 - Discussion started: 1 August 2017

Revised: 29 July 2018 - Accepted: 6 August 2018 - Published: 20 August 2018

\begin{abstract}
Atmospheric trace elements, especially metal species, are an emerging environmental and health concern with insufficient understanding of their levels and sources in Shanghai, the most important industrial megacity in China. Here we continuously performed a 1 year (from March 2016 to February 2017) and hourly resolved measurement of 18 elements in fine particles $\left(\mathrm{PM}_{2.5}\right)$ at the Shanghai urban center with an Xact multi-metals monitor and several collocated instruments. Mass concentrations (mean $\pm 1 \sigma ; \mathrm{ng} \mathrm{m}^{-3}$ ) determined by Xact ranged from detection limits (nominally 0.1 to $20 \mathrm{ng} \mathrm{m}^{-3}$ ) to $15 \mu \mathrm{g} \mathrm{m}^{-3}$. Element-related oxidized species comprised an appreciable fraction of $\mathrm{PM}_{2.5}$ during all seasons, accounting for $8.3 \%$ on average. As a comparison, the atmospheric elements concentration level in Shanghai was comparable with that in other industrialized cities in East Asia but 1 or 2 orders of magnitude higher than at sites in North America and Europe. Positive matrix factorization (PMF) was applied to identify and apportion the sources of the elements in the $\mathrm{PM}_{2.5}$ mass. Five different factors were resolved (notable elements and relative contri-
\end{abstract}

bution in parentheses): traffic-related (Ca, $\mathrm{Fe}, \mathrm{Ba}, \mathrm{Si} ; 46 \%)$, shipping (V, Ni; 6\%), nonferrous metal smelting (Ag, Cd, $\mathrm{Au} ; 15 \%$ ), coal combustion (As, $\mathrm{Se}, \mathrm{Hg}, \mathrm{Pb} ; 18 \%$ ) and ferrous metal smelting $(\mathrm{Cr}, \mathrm{Mn}, \mathrm{Zn} ; 15 \%)$. The contribution from the exhaust and non-exhaust vehicle emissions, i.e., the traffic-related factor shows a strong bimodal diurnal profile with average concentration over 2 times higher during the rush hour than during nighttime. The shipping factor was firmly identified because $\mathrm{V}$ and $\mathrm{Ni}$, two recognized tracers of shipping emissions, are almost exclusively transported from the East China Sea and their ratio (around 3.2) falls within the variation range of $\mathrm{V} / \mathrm{Ni}$ ratios in particles emitted from heavy oil combustion. Interestingly, nearly half of the $\mathrm{K}$ was derived from coal combustion with high mineral affinity (elements associated with aluminosilicates, carbonates and other minerals in coal ash). The contributions of nonferrous metal smelting to the trace elements are consistent with a newly developed emission inventory. Although the precipitation scavenging effect on the mass concentration of the trace elements varied among different species and sources, precipi- 
tation could effectively lower the concentration of the trafficand coal combustion-related trace elements. Therefore, water spray to simulate natural types of precipitation could be one of the abatement strategies to facilitate the reduction of ambient $\mathrm{PM}_{2.5}$ trace elements in the urban atmosphere. Collectively, our findings in this study provide baseline levels and sources of trace elements with high detail, which are needed for developing effective control strategies to reduce the high risk of acute exposure to atmospheric trace elements in China's megacities.

\section{Introduction}

It is well known that personal exposure to atmospheric aerosols have detrimental consequences and aggravating effects on human health such as respiratory, cardiovascular and allergic disorders (Pope III et al., 2002, 2009; Shah et al., 2013; West et al., 2016; Burnett et al., 2014). Among the chemical components relevant for aerosol health effects, airborne heavy metals (a very imprecise term without authoritative definition; John, 2002, loosely referring to elements with atomic density greater than $4.5 \mathrm{~g} \mathrm{~cm}^{-3}$; Streit, 1991) are of particular concern as they typically feature unique properties of bioavailability and bioaccumulation (Morman and Plumlee, 2013; Tchounwou et al., 2012; Fergusson, 1990; Kastury et al., 2017), representing 7 of the 30 hazardous air pollutants identified by the United States Environmental Protection Agency (EPA) in terms of posing the greatest potential health threat in urban areas (see https://www.epa. gov/urban-air-toxics/urban-air-toxic-pollutants; last access: 1 August 2018). Depending on the aerosol composition, extent and time of exposure, previous studies have confirmed that most elemental components of fine particles $\left(\mathrm{PM}_{2.5}\right.$; particulate matter with aerodynamic diameter equal to or less than $2.5 \mu \mathrm{m}$ ) exert a multitude of significant diseases from pulmonary inflammation, to increased heart rate variability, to decreased immune response (Fergusson, 1990; Morman and Plumlee, 2013; Leung et al., 2008; Hu et al., 2012; Pardo et al., 2015; Kim et al., 2016).

Guidelines for atmospheric concentration limits of many trace elements are provided by the World Health Organization (WHO) (WHO, 2005). In urban atmospheres, ambient trace elements typically represent a small fraction of $\mathrm{PM}_{2.5}$ on a mass basis, while elemental species like $\mathrm{Cd}$, As, Co, $\mathrm{Cr}, \mathrm{Ni}, \mathrm{Pb}$ and $\mathrm{Se}$ are considered as human carcinogens even in trace amounts (Iyengar and Woittiez, 1988; Wang et al., 2006; Olujimi et al., 2015). It has been shown that $\mathrm{Cu}, \mathrm{Cr}$, $\mathrm{Fe}$ and $\mathrm{V}$ have several oxidation states that can participate in many atmospheric redox reactions (Litter, 1999; Brandt and van Eldik, 1995; Seigneur and Constantinou, 1995; Rubasinghege et al., 2010a), which can catalyze the generation of reactive oxygenated species (ROSs) that have been associated with direct molecular damage and with the induction of biochemical synthesis pathways (Charrier and Anastasio, 2012; Strak et al., 2012; Rubasinghege et al., 2010b; Saffari et al., 2014; Verma et al., 2010; Jomova and Valko, 2011). Additionally, lighter elements such as $\mathrm{Si}, \mathrm{Al}$ and $\mathrm{Ca}$ are the most abundant crustal elements next to oxygen, which can typically constitute up to $50 \%$ of the elemental species in remote continental aerosols (Usher et al., 2003; Ridley et al., 2016). These species are usually associated with the impacts of aerosols on respiratory diseases and climate (Usher et al., 2003; Tang et al., 2017).

Health effects of airborne elemental species are not only seen from chronic exposure, but also from short-term acute concentration spikes in the ambient air (Kloog et al., 2013; Strickland et al., 2016; Huang et al., 2012). In addition, atmospheric emissions, transport and exposure of trace elements to human receptors may depend upon rapidly evolving meteorological conditions and facility operations (Tchounwou et al., 2012; Holden et al., 2016). Typical ambient trace element sampling devices collect 12 to $24 \mathrm{~h}$ integrated average samples, which are then sent off to be lab analyzed in a time-consuming and labor-intensive way. As a consequence, daily integrated samples inevitably ignore environmental shifts with rapid temporality and thereby hinder the efforts to obtain accurate source apportionment results such as short-term elements pollution spikes related to local emission sources. In fact, during a short-term trace elements exposure event, 12 or $24 \mathrm{~h}$ averaged sample concentrations for elemental species like $\mathrm{Pb}$ and As may be one order of magnitude lower than the $4 \mathrm{~h}$ or $15 \mathrm{~min}$ average concentration from the same day (Cooper et al., 2010). Current source apportionment studies are mainly performed by statistical multivariate analysis such as receptor models (e.g., Positive Matrix Factorization, PMF), which could greatly benefit from high inter-sample variability in the source contributions through increasing the sampling time resolution. In this regard, continuous monitoring of ambient elemental species on a realtime scale is essential for studies on trace element sources and their health impacts.

Currently, there are only a few devices available for the field sampling of ambient aerosols with sub-hourly or hourly resolution, i.e., the streaker sampler, the DRUM (Davis Rotating-Drum Unit for Monitoring) sampler and the SEAS (Semi-continuous Elements in Aerosol Sampler) (Visser et al., 2015a, b; Bukowiecki et al., 2005; Chen et al., 2016). Mass loadings of trace elements collected by these samplers can be analyzed with highly sensitive accelerator-based analytical techniques, in particular particle-induced X-ray emission (PIXE) or synchrotron radiation X-ray fluorescence (SR-XRF) (Richard et al., 2010; Bukowiecki et al., 2005; Maenhaut, 2015; Traversi et al., 2014). More recently, Aerosol Time-Of-Flight Mass Spectrometry (ATOFMS) (Murphy et al., 1998; Gross et al., 2000; DeCarlo et al., 2006), the National Institute for Standards and Technology (NIST)-traceable reference aerosol generating method (QAG) (Yanca et al., 2006), distance-based detection 
in a multi-layered device (Cate et al., 2015), environmental magnetic properties coupled with support vector machine ( $\mathrm{Li}$ et al., 2017), and the Xact 625 automated multi-metals analyzer (Fang et al., 2015; Jeong et al., 2016; Phillips-Smith et al., 2017; Cooper et al., 2010) have been developed for more precise, accurate and frequent measurement of ambient elemental species. The Xact method is based on nondestructive XRF analysis of aerosol deposits on a moving filter tape, which has been validated by the US Environmental Technology Verification testing and several other field campaigns (Fang et al., 2015; Phillips-Smith et al., 2017; Jeong et al., 2016; Yanca et al., 2006; Cooper et al., 2010; Park et al., 2014; Furger et al., 2017).

Located at the heart of the Yangtze River delta (YRD), Shanghai is home to nearly 25 million people as of 2015 , making it the largest megacity in China (Chang et al., 2016). Shanghai city is one of the main industrial centers of China, playing a vital role in the nation's heavy industries, including but not limited to, steel making, petrochemical engineering, thermal power generation, auto manufacture, aircraft production and modern shipbuilding (Normile, 2008; Chang et al., 2016; Huang et al., 2011). Shanghai is China's most important gateway for foreign trade and has the world's busiest port, handling over 37 million standard containers in 2016 (see http://www.simic.net.cn/news_show.php?lan= en\&id=192101, last access: 1 August 2018). As a consequence, Shanghai is potentially subject to substantial quantities of trace element emissions (Duan and Tan, 2013; Tian et al., 2015). Ambient concentrations of trace element, especially $\mathrm{Pb}$ and $\mathrm{Hg}$, in the Shanghai atmosphere have been sporadically reported during the past two decades (Shu et al., 2001; Lu et al., 2008; J. Wang et al., 2013; Zheng et al., 2004; Huang et al., 2013; Wang et al., 2016). Of current interest are $\mathrm{V}$ and $\mathrm{Ni}$, which are often indicative of heavy oil combustion from ocean-going vessels (Fan et al., 2016; Liu et al., 2017). However, previous work rarely presented a full spectrum of elemental species in ambient aerosols. Furthermore, recent attribution of hospital emergency-room visits in China to $\mathrm{PM}_{2.5}$ constituents failed to take short-term variations of trace elements into account (Qiao et al., 2014), which could inevitably underestimate the toxicity of aerosols and potentially misestimate the largest influence of aerosol components on human health effects (Honda et al., 2017).

In this study, the first of its kind, we conducted a longterm and near real-time measurement of atmospheric trace elements in $\mathrm{PM}_{2.5}$ with a Xact multi-metals analyzer in Shanghai, China, from March 2016 to February 2017. The primary target of the present study is to elucidate the levels and sources of atmospheric trace elements in a complex urban environment, which can be used to support future health studies. Meanwhile, the potential effect of precipitation scavenging on the mass concentration of the trace elements was investigated to examine if water spray could be proposed as an effective approach to curb severe trace element pollution in China's urban atmosphere.

\section{Methods}

\section{$2.1 \quad$ Field measurements}

\subsubsection{Site description}

Figure 1a shows a map of eastern China with provincial borders and land cover, in which Shanghai city (provincial level) sits in the middle portion of China's eastern coast and its metropolitan area (indicated as the densely populated area in Fig. 1b) concentrated on the south edge of the mouth of the Yangtze River. The municipality borders the provinces of Jiangsu and Zhejiang to the north, south and west, and is bounded to the east by the East China Sea (Fig. 1a). Shanghai has a humid subtropical climate and experiences four distinct seasons. Winters are chilly and damp, with northwesterly winds from Siberia sometimes causing nighttime temperatures to drop below freezing. In summer, the airflow carries moist air from the Pacific Ocean to mainland China, and it also brings the main precipitation. The city is also susceptible to typhoons in summer and the beginning of autumn. Air pollution in Shanghai is low compared to other cities in northern China, such as Beijing, but still substantial by world standards, especially in winter (Han et al., 2015; Chang et al., 2017).

Field measurements were performed at the rooftop ( $18 \mathrm{ma.g.1.}$ ) of the Pudong Environmental Monitoring Center (PEMC; $31.2331^{\circ} \mathrm{N}, 121.5447^{\circ} \mathrm{E} ; \sim 7 \mathrm{~m}$ a.s.l.) in the Pudong New Area of southwestern Shanghai, a region with dense population (Fig. 1b). Pudong New Area is described as the "showpiece" of modern China due to its height-obsessed skyline and export-oriented economy. For the PEMC, there were no metal-related sources (except for road traffic) or high-rise buildings nearby to obstruct observations, so the air mass could flow smoothly. More broadly, as indicated in Fig. 1c, the PEMC is surrounded by a multitude of emission sources such as coal-fired power plants (CFPPs) in all directions and iron and steel smelting in the northwest. Furthermore, a high level of ship exhaust emissions in 2010 such as $\mathrm{V}$ (Fig. 1d) and Ni (Fig. 1e) in the YRD and the East China Sea within $400 \mathrm{~km}$ of China's coastline was recently quantified based on an automatic identification system model (Fan et al., 2016). Therefore, the PEMC can be regarded as an ideal urban receptor site of diverse emission sources. More information regarding the sampling site has been given elsewhere (Chang et al., 2016, 2017).

\subsubsection{Hourly elemental species measurements}

From 1 March 2016 to 28 February 2017, hourly ambient mass concentrations of 18 elements ( $\mathrm{Si}, \mathrm{Fe}, \mathrm{K}, \mathrm{Ca}, \mathrm{Zn}, \mathrm{Mn}$, $\mathrm{Pb}, \mathrm{Ba}, \mathrm{V}, \mathrm{Cu}, \mathrm{Cd}, \mathrm{As}, \mathrm{Ni}, \mathrm{Cr}, \mathrm{Ag}, \mathrm{Se}, \mathrm{Hg}$ and $\mathrm{Au}$ ) in $\mathrm{PM}_{2.5}$ were determined by a Xact multi-metals monitor (Model $\mathrm{Xact}^{\mathrm{TM}}$ 625, Cooper Environmental Services LLT, OR, USA) (Phillips-Smith et al., 2017; Jeong et al., 2016; Fang et al., 

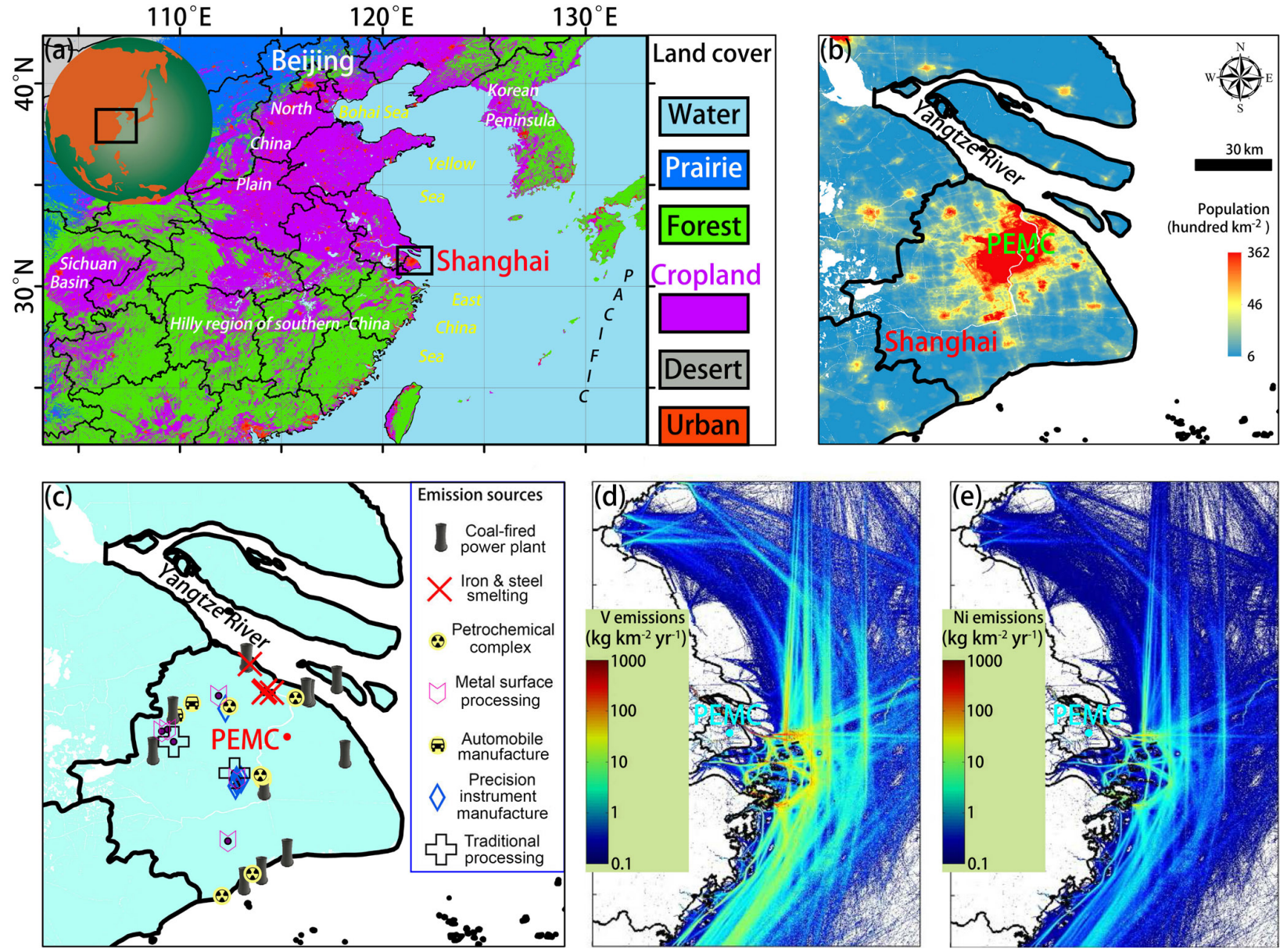

Figure 1. Land use map indicating the location of Shanghai (a; black box), as well as the population density (b) and the major point sources (c) around the sampling site (PEMC). The emissions of V (d) and Ni (e) from shipping in the YRD and the East China Sea within $400 \mathrm{~km}$ of the coastline were estimated based on an automatic identification system model (adopted from Fan et al., 2016).

2015; Yanca et al., 2006). Specifically, the Xact sampled the air on a reel-to-reel Teflon filter tape through a $\mathrm{PM}_{2.5}$ cyclone inlet (Model VSCC-A, BGI Inc., MA, USA) at a flow rate of $16.7 \mathrm{~L} \mathrm{~min}^{-1}$. The resulting $\mathrm{PM}_{2.5}$ deposit on the tape was automatically advanced into the analysis area for nondestructive energy-dispersive X-ray fluorescence analysis to determine the mass of selected elemental species as the next sampling was being initiated on a fresh tape spot. Sampling and analysis were performed continuously and simultaneously, except during advancement of the tape $(\sim 20 \mathrm{~s})$ and during daily automated quality assurance checks. For every event of sample analysis, the Xact included a measurement of pure $\mathrm{Pd}$ as an internal standard to automatically adjust the detector energy gain. The XRF response was calibrated using thin film standards for each elements of interest. These standards were provided by the manufacturer of the Xact, produced by depositing vapor phase elements on a blank Nuclepore filter (Micromatter Co., Arlington, WA, USA). The Nuclepore filter of known area was weighed before and after the vapor deposition process to determine the concentration $\left(\mu \mathrm{g} \mathrm{cm}^{-2}\right)$ of each element. In this study, excellent agreement between the measured and standard masses for each element was observed, indicating a deviation of $<5 \%$. The $1 \mathrm{~h}$ time resolution minimum detection limits (in $\mathrm{ng} \mathrm{m}^{-3}$ ) were: $\mathrm{Si}(17.80)$, $\mathrm{K}$ (1.17), Ca (0.30), V (0.12), Cr (0.12), Mn (0.14), Fe (0.17), $\mathrm{Ni}(0.10), \mathrm{Cu}(0.27), \mathrm{Zn}(0.23)$, As (0.11), Se (0.14), Ag (1.90), Cd (2.50), Au (0.23), Ba (0.39), $\mathrm{Hg}(0.12)$ and $\mathrm{Pb}$ (0.13).

As a reference method to validate the Xact on-line measurements, daily $\mathrm{PM}_{2.5}$ samples were also collected at the PEMC site using a four-channel aerosol sampler (Tianhong, Wuhan, China) on $47 \mathrm{~mm}$ cellulose acetate and glass fiber filters at a flow rate of $16.7 \mathrm{~L} \mathrm{~min}^{-1}$. The sampler was operated once a week with a $24 \mathrm{~h}$ sampling time (starting from 10:00 am). In total 48 filter samples ( 26 cellulose acetate filter samples and 22 glass fiber filter samples) were collected, in which eight paired samples were simultaneously collected by cellulose acetate and glass fiber filters. In the laboratory, the elemental analysis procedures strictly followed the latest national standard method "Ambient air and stationary 
source emission-Determination of metals in ambient particulate matter-Inductively coupled plasma/mass spectrometer (ICP-MS)" (HJ 657-2013) issued by the Chinese Ministry of Environmental Protection. A total of 24 elements (Al, Fe, $\mathrm{Mn}, \mathrm{Mg}, \mathrm{Mo}, \mathrm{Ti}, \mathrm{Sc}, \mathrm{Na}, \mathrm{Ba}, \mathrm{Sr}, \mathrm{Sb}, \mathrm{Ca}, \mathrm{Co}, \mathrm{Ni}, \mathrm{Cu}, \mathrm{Ge}, \mathrm{Pb}, \mathrm{P}$, $\mathrm{K}, \mathrm{Zn}, \mathrm{Cd}, \mathrm{V}, \mathrm{S}$ and As) were measured using the Inductively coupled plasma-mass spectrometer (ICP-MS; Agilent, CA, USA). The comparisons of different measurement methods (Xact vs. ICP-MS) and different collection substrates (glass filter vs. cellulose filter) are reported in Table S1 in the Supplement. In general, the data for elements like $\mathrm{K}, \mathrm{Cr}, \mathrm{Mn}, \mathrm{Fe}$, $\mathrm{Ni}, \mathrm{Cu}$ and $\mathrm{Au}$ proved to be of high quality, while elements like $\mathrm{As}, \mathrm{Cd}$ and $\mathrm{Ba}$ have relatively poor data quality.

\subsubsection{Auxiliary measurements, quality assurance and quality control}

Meteorological data, including ambient temperature $(T)$, relative humidity (RH), wind direction (WD) and wind speed (WS), were provided by the Shanghai Meteorological Bureau at Century Park station (located approximately $2 \mathrm{~km}$ away from the PEMC). The hourly mass concentrations of $\mathrm{PM}_{2.5}$ at the PEMC were measured by a particulate monitor (Thermo, FH62C-14). The routine procedures, including the daily zero or standard calibration, span and range check, station environmental control and staff certification, followed the Technical Guideline of Automatic Stations of Ambient Air Quality in Shanghai based on the national specification HJ/T193-2005. This was modified from the technical guidance established by the US EPA. Quality Assurance and Quality Control (QA/QC) for the Xact measurements was implemented throughout the campaign. The internal Pd, $\mathrm{Cr}, \mathrm{Pb}$ and $\mathrm{Cd}$ upscale values were recorded after the instrument's daily programmed test, and the $\mathrm{PM}_{10}$ and $\mathrm{PM}_{2.5}$ cyclones were cleaned weekly.

\subsection{Data analysis}

\subsubsection{Positive matrix factorization (PMF) analysis for source apportionment}

The Positive matrix factorization or PMF is an effective source apportionment method to identify and quantify possible emission sources of measurements using the bilinear factor model (Paatero and Tapper, 1994)

$x_{i j}=\sum_{k=1}^{p} g_{i k} f_{k j}+e_{i j}$,

where $x_{i j}$ is the $j$ th species concentration measured in the $i$ th sample, $g_{i k}$ is the contribution of the $k$ th source to the $i$ th sample (factor time series) and $f_{k j}$ is the concentration of the $j$ th species in the $k$ th source (factor profiles). The part of the data remaining unexplained by the model is represented by the residual matrix $e_{i j}$. The entries of $g_{i k}$ and $f_{k j}$ (required to be non-negative) are fit using a least-squares algorithm that iteratively minimizes the objective function $Q$ :

$Q=\sum_{i=1}^{n} \sum_{j=1}^{m}\left(\frac{e_{i j}}{\sigma_{i j}}\right)^{2}$.

where $\sigma_{i j}$ are the measurement uncertainties.

In this work, the US EPA PMF version 5.0 was applied to attribute $\mathrm{PM}_{2.5}$ trace elements to specific factors/sources. 1 year hourly resolved measurements $(n=8784)$ of 18 elements in the $\mathrm{PM}_{2.5}$ fraction were obtained and included for PMF analysis. The measurements $(n=1265)$ with missing data were excluded. An estimated fractional uncertainty of $10 \%$ was used to derive the uncertainty data set (Kim et al., 2005; Kim and Hopke, 2007), which did not impact the interpretability of the PMF results. The missing values of individual elements were replaced by their geometric mean of the remaining observations, and their accompanying uncertainties were set to 4 times the geometric mean. The measurements below detection limit (BDL) were set to half the detection limit, with uncertainties set at five-sixths the detection limit (Polissar et al., 1998). The EPA PMF 5.0 has three uncertainty estimation methods, including bootstrapping (BS), displacement (DISP) and bootstrapping enhanced with DISP (BS-DISP) (Norris et al., 2014; Brown et al., 2015; Paatero et al., 2014; Wang et al., 2017). BS-DISP analysis is time consuming due to the huge data set $(7519 \times 18)$, and only BS and DISP analysis were conducted individually. Details of the uncertainty analysis are described in the supporting information (Sect. S1). In this study, PMF solutions using 310 factors were considered, and the final factor number is determined based on the interpretability as well the uncertainty analysis with the BS and DISP methods.

\subsubsection{Conditional probability function and bivariate polar plot for tracing source regions}

The determination of the geographical origins of trace elements in Shanghai requires the use of diagnostic tools such as the conditional probability function $(\mathrm{CPF})$ and bivariate polar plot (BPP), which are very useful in terms of quickly gaining an idea of source impacts from various wind directions and have already been successfully applied to various atmospheric pollutants and pollution sources (Chang et al., 2017; Carslaw and Ropkins, 2012). In this study, the CPF and BPP were performed on the one-year data set for the major trace elements with a similar source. The two methods have been implemented in the R "openair" package and are freely available at http://www.openair-project.org/ (last access: 1 August 2018) (Carslaw and Ropkins, 2012).

The CPF is defined as $\mathrm{CPF}=m_{\theta} / n_{\theta}$, where $m_{\theta}$ is the number of samples in the wind sector $\theta$ with mass concentrations greater than a predetermined threshold criterion, and $n_{\theta}$ is the total number of samples in the same wind sector. CPF analysis is capable of showing which wind directions are dominated by high concentrations and with which probability. In this study, the 90th percentile of a given element 
species was set as threshold, and 24 wind sectors were used $\left(\Delta \theta=15^{\circ}\right)$. Calm wind $\left(<1 \mathrm{~m} \mathrm{~s}^{-1}\right)$ periods were excluded from this analysis due to the isotropic behavior of the wind vane under calm winds.

The BPP demonstrates how the concentration of a targeted species varies synergistically with wind direction and wind speed in polar coordinates, which is thus essentially a nonparametric wind regression model to alternatively display pollution roses but include some additional enhancements. These enhancements include plots being shown as a continuous surface and surfaces being calculated through modeling using smoothing techniques. These plots are not entirely new as others have considered the joint wind speed-direction dependence of concentrations (see for example Liu et al., 2015). However, plotting the data in polar coordinates and for the purposes of source identification is new. The BPP has been described in more detail in Carslaw et al. (2006) and the construction of BPP has been presented in our previous work (Chang et al., 2017).

\section{Results and discussion}

\subsection{Mass concentrations}

The temporal patterns and summary statistics of the hourly elemental species concentrations determined by the Xact at the PEMC during March 2016-February 2017 are presented in Fig. 2. The 1 year data set presented in the current study, to the best of our knowledge, represents the longest on-line continuous measurement series of atmospheric trace elements.

Taking the study period as a whole, the ambient average mass concentrations of the elemental species varied between the detection limit (ranging from 0.05 to $20 \mathrm{ng} \mathrm{m}^{-3}$ ) and nearly $15 \mu \mathrm{g} \mathrm{m}^{-3}$, with $\mathrm{Si}$ as the most abundant element (mean $\left.\pm 1 \sigma ; 640 \pm 1010 \mathrm{ng} \mathrm{m}^{-3}\right)$, followed by $\mathrm{Fe}(410 \pm$ $\left.390 \mathrm{ng} \mathrm{m}^{-3}\right), \mathrm{K}\left(390 \pm 330 \mathrm{ng} \mathrm{m}^{-3}\right), \mathrm{Ca}\left(190 \pm 380 \mathrm{ng} \mathrm{m}^{-3}\right)$, $\mathrm{Zn}\left(120 \pm 130 \mathrm{ng} \mathrm{m}^{-3}\right), \mathrm{Mn}\left(32 \pm 39 \mathrm{ng} \mathrm{m}^{-3}\right), \mathrm{Pb}(27 \pm$ $\left.26 \mathrm{ng} \mathrm{m}^{-3}\right), \mathrm{Ba}\left(24 \pm 25 \mathrm{ng} \mathrm{m}^{-3}\right), \mathrm{V}\left(13 \pm 15 \mathrm{ng} \mathrm{m}^{-3}\right), \mathrm{Cu}$ $\left(12 \pm 11 \mathrm{ng} \mathrm{m}^{-3}\right)$, Cd $\left(10 \pm 4 \mathrm{ng} \mathrm{m}^{-3}\right)$, As $\left(7 \pm 7 \mathrm{ng} \mathrm{m}^{-3}\right)$, $\mathrm{Ni}\left(6 \pm 5 \mathrm{ng} \mathrm{m}^{-3}\right), \mathrm{Cr}\left(5 \pm 6 \mathrm{ng} \mathrm{m}^{-3}\right), \mathrm{Ag}\left(4 \pm 2.6 \mathrm{ng} \mathrm{m}^{-3}\right)$, $\mathrm{Se}\left(2.6 \pm 2.9 \mathrm{ng} \mathrm{m}^{-3}\right), \mathrm{Hg}\left(2.2 \pm 1.7 \mathrm{ng} \mathrm{m}^{-3}\right)$ and $\mathrm{Au}(2.2 \pm$ $3.4 \mathrm{ng} \mathrm{m}^{-3}$ ). According to the ambient air quality standards of China (GB 3095-2012), EU (DIRECTIVE 2004/107/EC) and $\mathrm{WHO}$, the atmospheric concentration limits for $\mathrm{Cd}, \mathrm{Hg}$, As, Cr (VI), Mn, V and Ni are 5, 50 (1000 for WHO), 6 (6.6 for WHO), 0.025, 150 (WHO), 1000 (WHO) and 20 ( 25 for WHO) $\mathrm{ng} \mathrm{m}^{-3}$, respectively. Therefore, the airborne metal pollution in Shanghai is generally low by the current limit ceilings. Nevertheless, information regarding the specific metal compounds or chemical forms is rarely available given that most analytical techniques only record data for the total metal content. In the absence of this type of information, it is generally assumed that many of the elements of anthropogenic origin (especially from combustion sources) are present in the atmosphere as oxides. Here we reconstructed the average mass concentrations of metal and crustal oxides as 5.2, 5.0, 2.8 and $3.1 \mu \mathrm{g} \mathrm{m}^{-3}$ in spring, summer, fall and winter, respectively, while the annual average concentration was $3.9 \mathrm{\mu g} \mathrm{m}^{-3}$, accounting for $8.3 \%$ of the total $\mathrm{PM}_{2.5}$ mass $\left(47 \mu \mathrm{g} \mathrm{m}^{-3}\right)$ in 2016 . Detailed calculation of the reconstructed mass has been fully described elsewhere (Dabek-Zlotorzynska et al., 2011).

The toxicological effect of hazardous elemental species is more evident and well known in soils and aquatic ecosystems, while few (if any) studies on the geochemical cycle of trace metals have considered the fast dynamics of trace elements in the atmosphere. Using a diversity of chemical, physical, and optical techniques, elevated atmospheric concentrations of various element species have been observed globally; however, a tiny minority of them were performed with high time resolution. As a comparison, we compiled previous work related to the near real-time measurements of trace element concentrations in Table 1 . The concentrations of most trace elements in Shanghai were commonly one or two orders of magnitude higher than those measured in Europe and North America, and generally were of the same level as in industrialized cities like Kwangju in South Korea. Exceptionally, the concentrations of $\mathrm{V}$ and $\mathrm{Ni}$ in Shanghai were up to 3 times higher than those at Kwangju City. This is expected as Shanghai has the world's busiest container port and $\mathrm{V}$ and $\mathrm{Ni}$ were substantially and almost exclusively emitted from heavy oil combustion in ship engines of ocean-going vessels (see more discussion in Sect. 3.2 and 3.3).

In contrast to traditional trace element measurements, the on-line XRF used in the current study enables measurement of elemental species concentrations with $1 \mathrm{~h}$ resolution, which are useful both for source discrimination and in determining the processes contributing to elevated trace element levels through investigation of their seasonal, weekly, weekday-weekend and diurnal cycles (Figs. S2-S8; see discussion below).

\subsection{Source analysis}

In the PMF analysis, three to ten factor solutions were initially examined, from which possible solutions (i.e., four to six factor solutions) were chosen based on the change of $Q / Q_{\text {exp }}$, the achievement of a constant and global minimum of $Q$, the displacement of factor elements and the interpretation of physically meaningful factors (Sect. S1; see discussion below). The most reliable solution was obtained with five factors. The chemical profiles and average contributions of the five factors are presented in Fig. 3 with the timeseries evolution of these factors included in the Supplement (Fig. S9). On the one hand, we will use various mathematical and physical criteria to constrain different solutions of source apportionment. On the other hand, we will take CPF and BPP as diagnostic tools for quickly gaining the idea of potential source regions, which in turn will contribute to fur- 
(a)

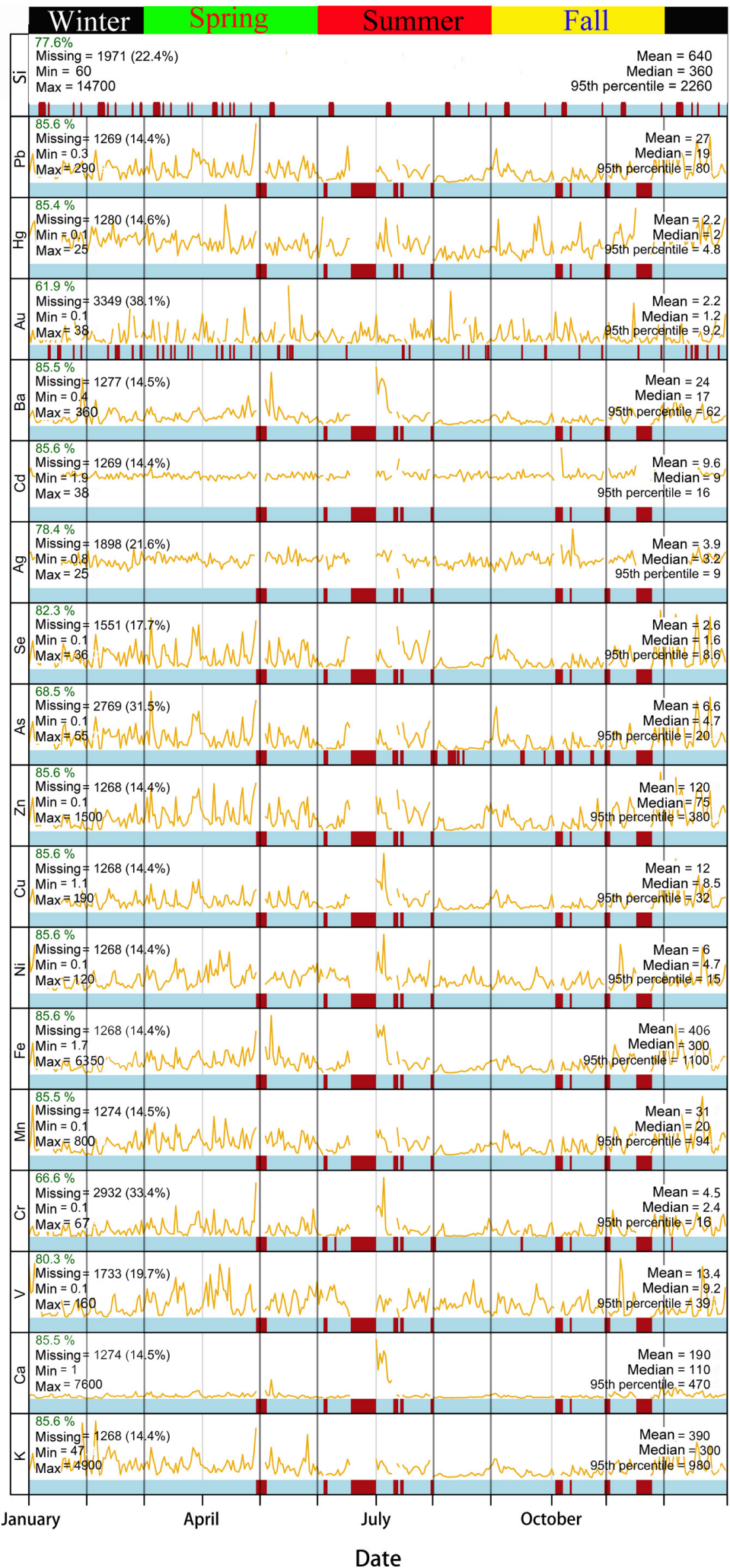

(b)
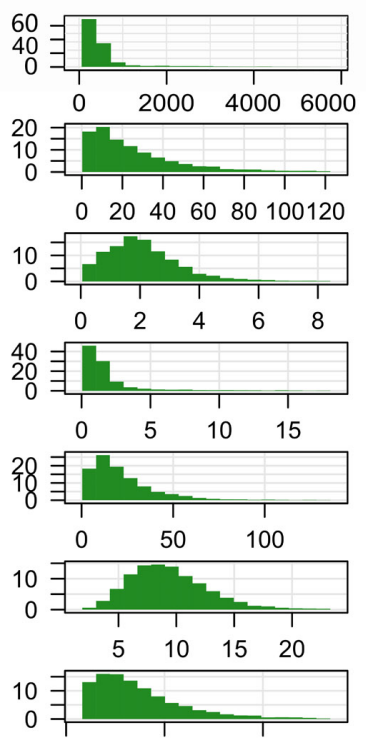

$5 \quad 10$
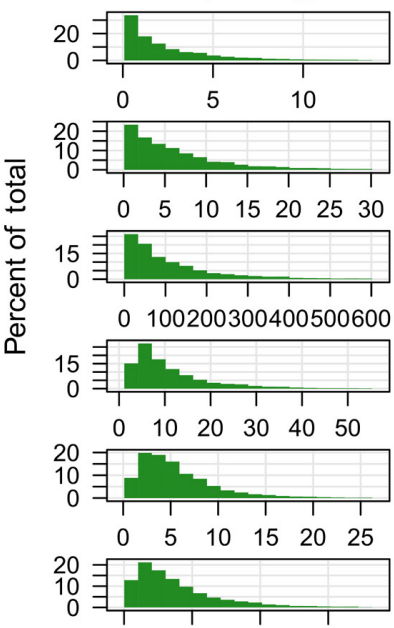

$0 \quad 500 \quad 1000 \quad 1500$

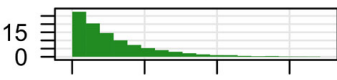

$\begin{array}{llll}0 & 50 & 100 & 150\end{array}$

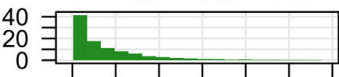

$\begin{array}{lllllll}0 & 5 & 10 & 15 & 20 & 25 & 30\end{array}$

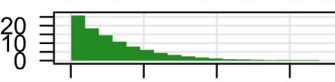

$0 \quad 20 \quad 40 \quad 60$

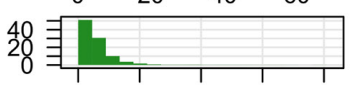

$0 \quad 500100015002000$

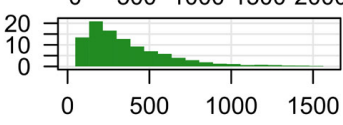

Value

Figure 2. General statistical summary of 18 trace elements measured in Shanghai. The plots in panel (a) show the time series data, where blue shows the presence of data and red shows missing data. The mean daily values are shown in pale yellow, scaled to cover the range in the data from zero to the maximum daily value. As such, the daily values are indicative of an overall trend rather than conveying quantitative information. For each elemental species (at hourly resolution), the overall summary statistics are given. Panel (b) on the right shows the distribution of each elemental species using a histogram plot. 
Table 1. Overview of long-term and high-time resolution measurements of ambient trace elements concentrations $\left(\mathrm{ng} \mathrm{m}^{-3}\right)$ in fine particles.

\begin{tabular}{lrrrrrrr}
\hline Species & $\begin{array}{r}\text { Shanghai, } \\
\mathrm{CN}^{a}\end{array}$ & $\begin{array}{r}\text { Gwangju, } \\
\mathrm{KP}^{b}\end{array}$ & $\begin{array}{r}\text { London, } \\
\mathrm{UK}^{c}\end{array}$ & $\begin{array}{r}\text { London, } \\
\mathrm{UK}^{d}\end{array}$ & $\begin{array}{r}\text { Barcelona, } \\
\mathrm{ES}^{e}\end{array}$ & $\begin{array}{r}\text { Wood Buffalo, } \\
\mathrm{CA}^{f}\end{array}$ & $\begin{array}{r}\text { Toronto, } \\
\mathrm{CA}^{g}\end{array}$ \\
\hline $\mathrm{Ag}$ & 3.9 & $/$ & $/$ & $/$ & $/$ & $/$ & $/$ \\
$\mathrm{As}$ & 6.6 & 9.6 & $/$ & $/$ & $/$ & $/$ & $/$ \\
$\mathrm{Au}$ & 2.2 & $/$ & $/$ & $/$ & $/$ & $/$ & $/$ \\
$\mathrm{Ba}$ & 24 & 52 & 10 & 3.7 & $/$ & $/$ & 1.9 \\
$\mathrm{Ca}$ & 190 & 120 & 79 & 50 & 130 & 54 & 54 \\
$\mathrm{Cd}$ & 9.6 & $/$ & $/$ & $/$ & $/$ & $/$ & $/$ \\
$\mathrm{Cr}$ & 4.5 & $/$ & 2.3 & 0.8 & 8.0 & 0.04 & 0.24 \\
$\mathrm{Cu}$ & 12 & 15.5 & 13 & 4.9 & 8.0 & 2.0 & 3.1 \\
$\mathrm{Fe}$ & 410 & 290 & 350 & 120 & 130 & 60 & 77 \\
$\mathrm{Hg}$ & 2.2 & $/$ & $/$ & $/$ & $/$ & $/$ & $/$ \\
$\mathrm{K}$ & 390 & 730 & 27.2 & 24 & 82 & 31 & 27 \\
$\mathrm{Mn}$ & 32 & 24 & 4.8 & 2.5 & 6.0 & 1.1 & 1.8 \\
$\mathrm{Ni}$ & 6.0 & 3.8 & 0.5 & 0.2 & 3.0 & 0.08 & 0.21 \\
$\mathrm{~Pb}$ & 27 & 49 & 2.3 & 1.8 & 12 & $/$ & 2.4 \\
$\mathrm{Se}$ & 2.6 & 4.3 & $/$ & $/$ & $/$ & $/$ & 0.3 \\
$\mathrm{Si}$ & 640 & $/$ & $/$ & $/$ & $/$ & 140 & $/$ \\
$\mathrm{V}$ & 13 & 4.6 & 1.3 & 0.6 & 8.0 & 0.21 & 0.11 \\
$\mathrm{Zn}$ & 120 & 100 & 8.9 & 5.3 & 25 & 0.88 & 11 \\
\hline
\end{tabular}

${ }^{a}$ this study; ${ }^{b}$ Park et al. (2014); ${ }^{c} \mathrm{PM}_{0.3-2.5}$, Marylebone Road, London (Visser et al., 2015b); ${ }^{d} \mathrm{PM}_{0.3-2.5}$, North Kensington, London (Visser et al., 2015b); ${ }^{e}$ a road site in Barcelona (Dall'Osto et al., 2013); ${ }^{f}$ Phillips-Smith et al. (2017); ${ }^{g}$ Sofowote et al. (2015). We noticed that a huge data set of hourly resolved trace metals had been reported in Jeong et al. (2016) and Visser et al. (2015a), but that no detailed information regarding the specific mass concentrations of trace elements was given.

ther analysis of source apportionment. Ultimately, the five factors were assigned to different sources, i.e., traffic-related, shipping, nonferrous metal smelting, coal combustion and ferrous metal smelting.

\subsubsection{Traffic-related}

Factor 1 was characterized by a large mass fraction of $\mathrm{Ca}$, $\mathrm{Fe}, \mathrm{Ba}$ and $\mathrm{Si}$, which explained $90 \%, 50 \%, 77 \%$ and $63 \%$ of the concentration, respectively. This mixed factor is similar to that reported by Amato et al. (2009, 2013), Bukowiecki et al. (2010), Harrison et al. (2012) and Visser et al. (2015b). In the urban atmosphere, $\mathrm{Fe}$ can be released from engine oil or catalyst equipped gasoline vehicles (Chen et al., 2007). Besides, $\mathrm{Fe}$ is linked to non-exhaust emissions such as brake wear because it is the support material for brake pads and the agents present in brake linings typically consist of $\mathrm{Ba}$, $\mathrm{Mn}$ and $\mathrm{Cu}$ (Lough et al., 2005; Hjortenkrans et al., 2007; Dall'Osto et al., 2016). Therefore, Fe and Ba can be regarded as chemical tracers for a traffic-related source (exhaust and non-exhaust) (Thorpe and Harrison, 2008; Lin et al., 2015). $\mathrm{Ca}$ and $\mathrm{Si}$ are known as two of the most abundant elements in the upper continental crust, and their atmospheric origin is typically attributed to wind-blown dust. Located on the eastern coast of China, Shanghai rarely receives long-range transport of crustal matter from aeolian dust and the Gobi Desert in northwestern China (Huang et al., 2013). Sampling in the urban area of Shanghai, airborne $\mathrm{Ca}$ and $\mathrm{Si}$ should be dominated by anthropogenic activities like road fugitive dust or urban construction works. In Fig. S10, significant correlations are observed for $\mathrm{Ca}, \mathrm{Si}, \mathrm{Fe}$ and $\mathrm{Ba}$, suggesting that the measured $\mathrm{Ca}$ and $\mathrm{Si}$ during our study period were more likely derived from road fugitive dust. Therefore, factor 1 can be assigned to a traffic-related source and it was the largest source in Shanghai, accounting for $46 \%\left(680 \mathrm{ng} \mathrm{m}^{-3}\right)$ of the total measured elemental mass in $\mathrm{PM}_{2.5}$.

Hourly measurements over one-year periods provide a unique opportunity to examine the diurnal profile of factor 1. As reported in Fig. 4, the concentration of the trace elements contributed by factor 1 shows a marked bimodal diurnal cycle, with average values at rush hours that are over 2 times higher than at nighttime. Such variation pattern agrees well with the diurnal variation of the traffic flow in Shanghai (Chang et al., 2016), further confirming that factor 1 can be interpreted as traffic-related emissions.

\subsubsection{Shipping}

In Fig. 3, V (100\%) and Ni (74\%) come almost exclusively from factor 2 , while factor 2 contributes to less than $10 \%$ of any other elemental species. $\mathrm{V}$ is typically emitted from oil and petrochemical refining and combustion, and natural gas extraction and processing (Duce and Hoffman, 1976; Hope, 1994; Shafer et al., 2012). From CPF and BPP analysis (Fig. S11), higher concentrations of both $\mathrm{V}$ and Ni were observed when winds originated from the east, northeast and 


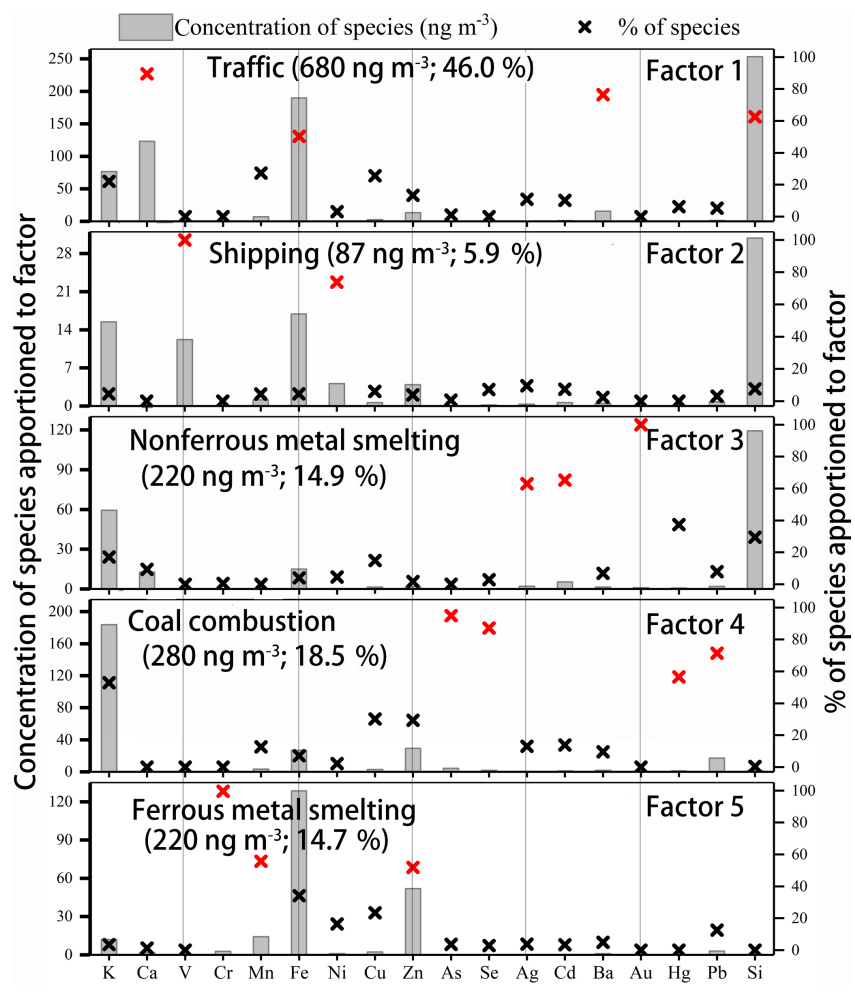

Figure 3. PMF-resolved source profiles (concentration and \% of species apportioned to the factor) and average contributions (in the parentheses) of individual sources to the measured total $\mathrm{PM}_{2.5}$ elements in Shanghai. The notable species for each factor and source are marked in red.

southeast directions. The most dominant directions were east and southeast, suggesting the influence from the coastal port cluster or petroleum refinery industry located east/southeast of Shanghai (Fig. 1). Gathering evidence revealed that the ratio of $\mathrm{V} / \mathrm{Ni}$ can serve as a robust indicator of shipping emissions (Tao et al., 2013; Celo et al., 2015; Liu et al., 2017; Viana et al., 2009). A recent study in Shanghai port suggested that the ratio of $\mathrm{V} / \mathrm{Ni}$ in aerosols emitted from heavy oil combustion of ocean-going ship engines was 3.4 on average (Zhao et al., 2013). Here measured in the urban area, the average ratio of $\mathrm{V} / \mathrm{Ni}$ in our study was 3.2 with slight seasonal changes (Fig. 5), indicating V- and Ni-containing aerosols from shipping emissions subject to minor atmospheric transformation. In short, factor 2 likely corresponds to shipping emissions (instead of petrochemical refining), which is consistent with the results of many previous source apportionment works (e.g., Liu et al., 2017; Zhao et al., 2013; Cesari et al., 2014; Healy et al., 2010).

Although shipping emissions only contribute to $5.9 \%$ of the trace elements in the Shanghai urban center, their share can be expected to greatly increase in the harbor district (Zhao et al., 2013). The good news is that since 1 January 2016, the sea areas of Shanghai and the neighboring ports were designed as shipping emission control area, re-

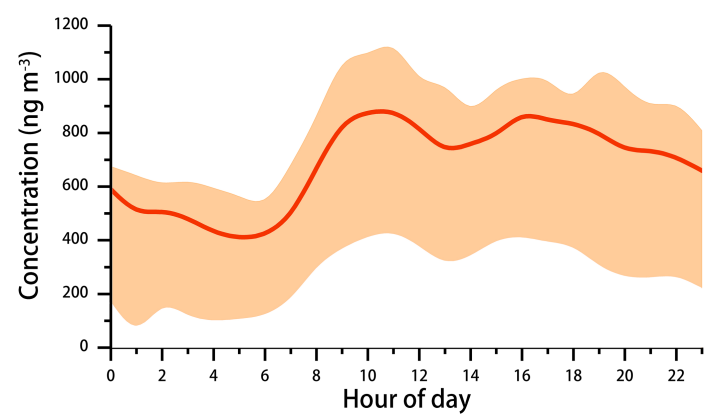

Figure 4. Diurnal variation of PMF-derived elemental concentration for factor 1 . The red line, bottom boundary and upper boundary represent the mean, 1st quartile and 3rd quartile of the concentration value, respectively.

quiring use of lower sulfur fuels in place of heavy fuel oil in the main engines of the ships (Zhen et al., 2018). Therefore, it is critically important to assess the impacts of fuel changes on the air quality in Shanghai in the future through continuous measurements of trace elements.

\subsubsection{Nonferrous metal smelting}

The predominant elements found in factor 3 were $\mathrm{Au}(100 \%), \mathrm{Cd}(65 \%)$ and $\mathrm{Ag}(63 \%)$ with $37 \%$ of $\mathrm{Hg}$. These four heavy metals are important associated elements in $\mathrm{Cu}, \mathrm{Pb}$ and $\mathrm{Zn}$ ores. In fact, $\mathrm{Cu}, \mathrm{Pb}$ and $\mathrm{Zn}$ smelting represent the three most common forms of nonferrous metal smelting in China (Tian et al., 2015). Due to high temperatures during the roasting, sintering and smelting process for the extraction of $\mathrm{Cu}, \mathrm{Pb}$ and $\mathrm{Zn}$ from ores, metals like $\mathrm{Au}, \mathrm{Cd}, \mathrm{Ag}$ and $\mathrm{Hg}$ in nonferrous metal ores will inevitably be vaporized and released into the flue gas (Pacyna and Pacyna, 2001; Wu et al., 2012). Therefore, factor 3 was interpreted as nonferrous metal smelting emissions and the contribution of this factor was $15 \%\left(220 \mathrm{ng} \mathrm{m}^{-3}\right)$ to the total measured elemental mass in $\mathrm{PM}_{2.5}$.

To further pinpoint the specific subsector of nonferrous metal smelting, here we calculate percentile concentration levels of $\mathrm{Au}$ and $\mathrm{Hg}$, and plot them by wind direction in Fig. 6 (and $\mathrm{Ag}, \mathrm{Cd}$ in Fig. S12). It clearly shows that $\mathrm{Au}$ and $\mathrm{Hg}$ largely share the same source region which is different from that for $\mathrm{Ag}$ and $\mathrm{Cd}$, indicating that $\mathrm{Au}$ and $\mathrm{Hg}$ were emitted from a similar subsector of nonferrous metal smelting. In Shanghai, Zn smelting is the most important contributor of $\mathrm{Hg}$ emissions from the nonferrous metal smelting sector. Therefore, the element Au resolved in factor 3 during our study period can be expected to be originated from $\mathrm{Zn}$ smelting.

\subsubsection{Coal combustion}

The most abundant elements found in factor 4 were As, Se, $\mathrm{Pb}, \mathrm{Hg}$ (explaining $56 \%$ to $95 \%$ of the concentration) with 


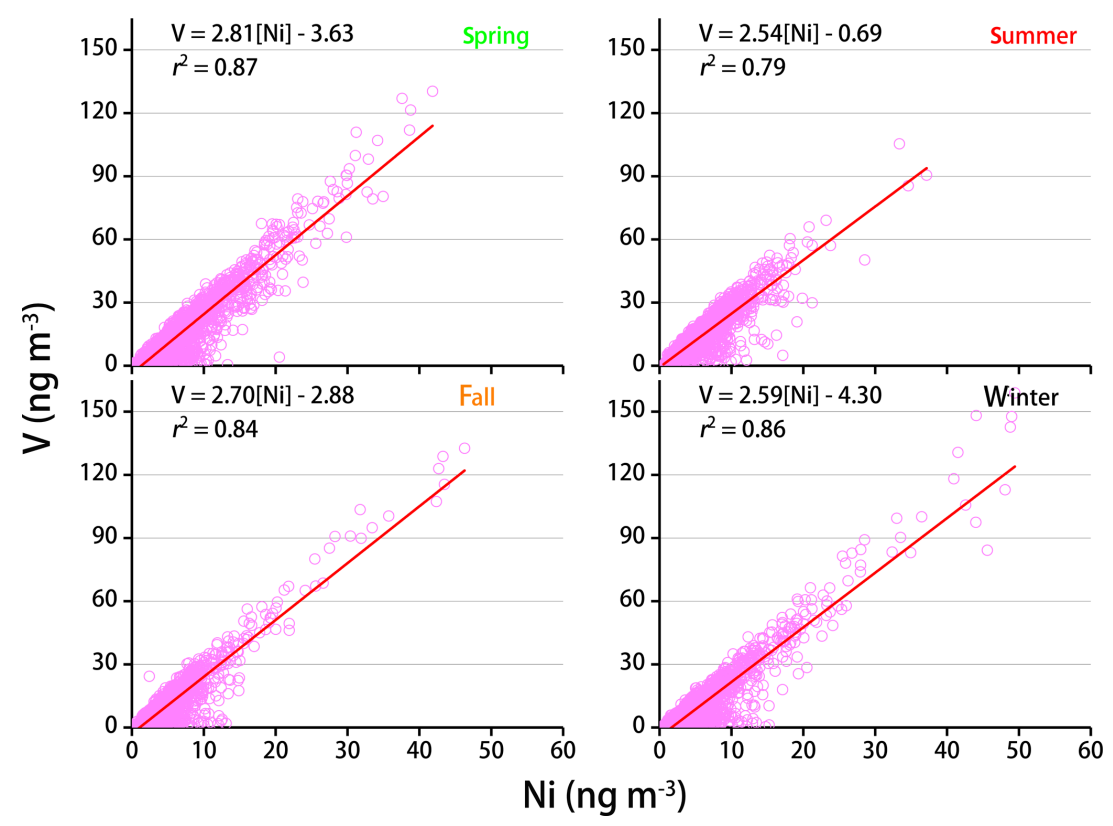

Figure 5. Linear correlation analysis between $\mathrm{Ni}(x$ axis) and V ( $y$ axis) in Shanghai during the four seasons.

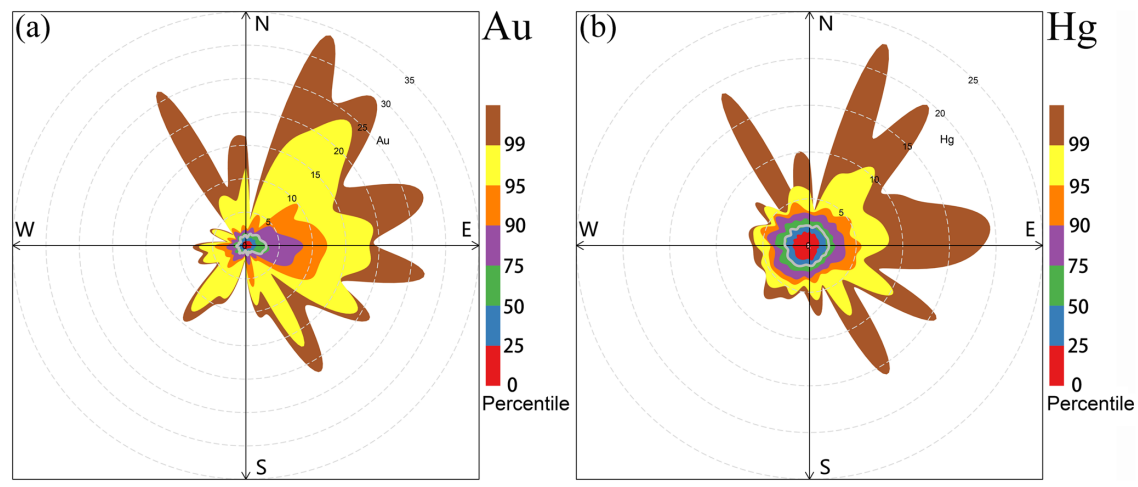

Figure 6. Percentile rose plot of $\mathrm{Au}$ (a) and $\mathrm{Hg}$ (b) concentrations in Shanghai between March 2016 and February 2017. The percentile intervals are shaded and shown by wind direction.

some contributions of $\mathrm{Cu}(30 \%), \mathrm{Zn}(29 \%)$ and an unexpected large amount of $\mathrm{K}(53 \%)$. As, $\mathrm{Se}, \mathrm{Pb}, \mathrm{Hg}$ and $\mathrm{Cu}$ are typical marker elements for coal combustion (Morawska and Zhang, 2002). In China, $73 \%$ of As, $62 \%$ of Se, $56 \%$ of $\mathrm{Pb}$ and $47 \%$ of $\mathrm{Hg}$ were found to be emitted from coal combustion (Tian et al., 2015). Coal consumption in southern China (including Shanghai) is mainly driven by industrial boilers and power plant, while in northern China, coalbased heating is also a major sector of coal consumption (Tian et al., 2015). Seasonally, the average mass concentration of coal combustion-related $\mathrm{PM}_{2.5}$ trace elements during winter $\left(410 \mathrm{ng} \mathrm{m}^{-3}\right)$ was much higher than that during spring (270 $\left.\mathrm{ng} \mathrm{m}^{-3}\right)$, summer $\left(150 \mathrm{ng} \mathrm{m}^{-3}\right)$ and fall $\left(210 \mathrm{ng} \mathrm{m}^{-3}\right)$ (Fig. 7). This seasonal pattern was not observed for other sources (not shown). Shanghai has a humid subtropical climate and experiences four distinct seasons. Winters are chilly and damp, with northwesterly winds from northern China transporting air pollutants (including trace elements) caused by coal-based heating to the Shanghai atmosphere (Huang et al., 2013; Chang et al., 2017). As the largest city-scale coal consumer in China, coal combustion contributed to $280 \mathrm{ng} \mathrm{m}^{-3}$ or $19 \%$ of the $\mathrm{PM}_{2.5}$ trace elements during our study period.

Traditionally, $\mathrm{K}$ in particles is considered to originate from biomass burning along with some contribution of fugitive dust (Zhang et al., 2010; Hueglin et al., 2005; Fang et al., 2015). Here we show that over half of the element $K$ in urban Shanghai was derived from coal combustion. The reason for this discrepancy may be that in most previous studies, $\mathrm{K}$ in particles was pretreated using deionized water to extract (X. Wang et al., 2013). In fact, $\mathrm{K}$ has a high mineral affinity (elements associated with aluminosilicates, carbon- 


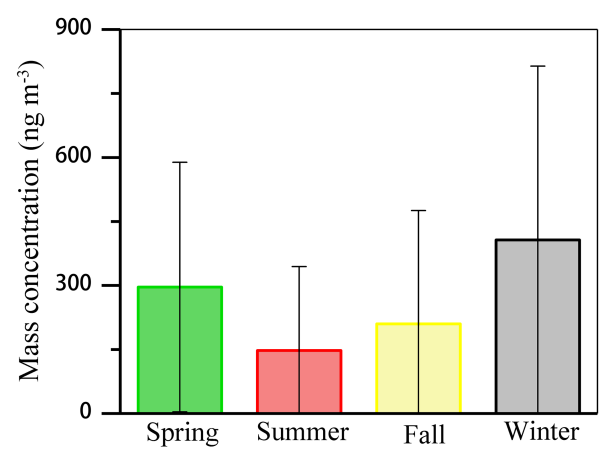

Figure 7. Seasonal variation of elemental concentrations contributed by coal combustion in Shanghai. The error bar indicates one standard derivation.

ates and other minerals in coal ash), and in some extreme cases, only about $1 \%$ of $\mathrm{K}$ in fly ash from coal combustion can be extracted by water (Querol et al., 1996). For example, particles collected from coal combustion by X. Wang et al. (2013) were extracted with deionized water, then atomized and measured by an ATOFMS. The ATOFMS mass spectrum contained a relatively low $\mathrm{K}$ peak. The observation by X. Wang et al. (2013) was not consistent with that of Suess (2002), who observed larger K peaks in ATOFMS spectra for coal combustion particles in an in situ measurement (i.e., freshly emitted particles were directly introduced into the ATOFMS and measured).

\subsubsection{Ferrous metal smelting}

Factor 5 was distinguished by high levels of $\mathrm{Cr}, \mathrm{Mn}$ and $\mathrm{Zn}$ representing $100 \%, 56 \%$ and $52 \%$ of the concentration, respectively. These elements are typically emitted from ferrous metal smelting. For example, the steel production industry represents the dominant contributor to $\mathrm{Zn}$ emissions, accounting for about $60 \%$ in China (Tian et al., 2015). Driven by rapid modernization of its infrastructure and manufacturing industries, China produced more than $49 \%$ of world steel production in 2017 (around 830 million tons), and 6 of 10 of the largest steel producers are in China (data retrieved from https://www.worldsteel.org, last access: $1 \mathrm{Au}-$ gust 2018). Headquartered in Shanghai (20 km northwest of the sampling site), the Baosteel is the fifth-largest steel producer in the world measured by crude steel output, with an annual output of around 35 million tons. Meanwhile, there are several factories of ferrous metal processing located in western Shanghai (Fig. 1). As the element $\mathrm{Cr}$ is reported to be transported over substantial distances by the air (Perry et al., 1999), the presence of ferrous metal smelting activities in the west-northwest of the sampling site is inferred to be associated with this factor based on the results of CPF and BBP in Fig. 8. Overall, ferrous metal smelting contributed $220 \mathrm{ng} \mathrm{m}^{-3}$ or $15 \%$ of the $\mathrm{PM}_{2.5}$ trace elements in Shanghai.

\subsection{Precipitation effect}

Theoretically, precipitation could enhance the wet scavenging of airborne pollutants and reduce their ability to suspend, as the increased moisture might capture the particles (Kuhns et al., 2003; Karanasiou et al., 2011). Water spray (from sprinkler on road or atop a tall building) to simulate natural types of precipitation has been proposed as an important abatement strategy to facilitate the reduction of ambient PM concentrations (including trace elements) in urban China (Liu et al., 2014; Yu, 2014). However, several field measurements revealed that water spray activities did not influence the PM mass levels (e.g., Karanasiou et al., 2012; Karanasiou, 2014). Taking advantage of our simultaneous and hourly record of the precipitation amount (up to $37 \mathrm{~mm}$ ) and the elemental concentration, here we evaluate the effects of precipitation on the mitigation of $\mathrm{PM}_{2.5}$ trace elements. The precipitation (all were in the form of rainfall) distributed during the full year of measurements is shown in Fig. S13. The mass concentrations of the trace elements $6 \mathrm{~h}$ before and after precipitation events were compared from the perspective of individual species and sources. A precipitation event in this study is defined as (1) at least six consecutive hours with an hourly rainfall amount higher than $1 \mathrm{~mm}$; (2) consecutive no-rainy time in a precipitation event should be less than $6 \mathrm{~h}$; (3) total no-rainy time should be less than $1 / 3$ of the entire time of a precipitation event; and (4) if the rainfall amount of a specific hour is less than $0.1 \mathrm{~mm}$, and there are at least three no-rainy hours before and after the rainy hour, then this hour should be treated as a no-rainy hour. Consequently, 12 precipitation events during our study period were identified with a duration time and accumulated rainfall ranging from 7 to $55 \mathrm{~h}$ and 26 to $220 \mathrm{~mm}$, respectively (Table S2).

\subsubsection{Change of mass concentration by species}

The average mass concentration of each elemental species before, during and after every precipitation event is presented in Fig. S14. If precipitation effectively scavenges and removes aerosol, then the mass concentrations of trace elements during a precipitation event should be lower than that before and after this precipitation event. However, there is no uniform variation pattern in Fig. S14, indicating that precipitation may not be the predominant factor to influence the ambient elemental mass in some cases. For example, most elemental species had a relatively higher mass concentration during the 12th precipitation event (which lasted from 09:00 25 December to 22:00 26 December; Fig. S14). This can be explained by the much less anthropogenic activities during the periods prior to (03:00 to 08:00) and after (23:00 to 03:00 the next day) the 12th precipitation event.

For each elemental species, the variation of mass concentration before, during and after every precipitation event was aggregated and reported in Fig. 9a. Before the precipitation events, the mass concentrations of all species except $\mathrm{Cr}$ and 


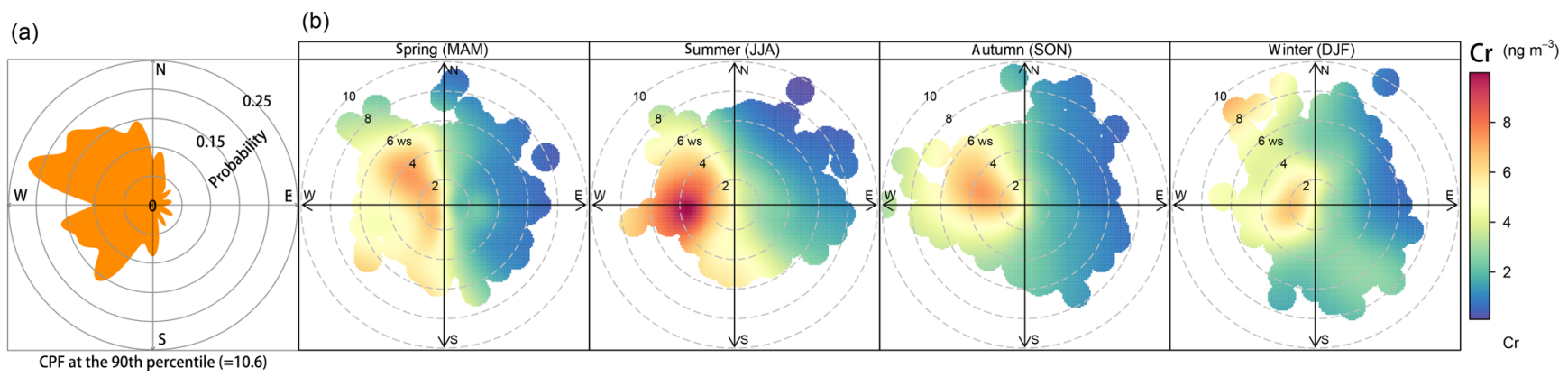

Figure 8. Conditional probability function analysis (a) and bivariate polar plots (b) of seasonal concentrations (in $\mathrm{ng} \mathrm{m}^{-3}$ ) of $\mathrm{Cr}$ in Shanghai between March 2016 and February 2017. The center of each plot (centered at the sampling site) represents a wind speed of zero, which increases radially outward. The concentration is shown by the color scale.

$\mathrm{Au}$ were higher than those during the precipitation events (notably $\mathrm{V}, \mathrm{Zn}, \mathrm{Fe}$ ), suggesting that water spray could generally help to reduce the $\mathrm{PM}_{2.5}$ trace elements load in the atmosphere. After the precipitation events, there were six species (notably $\mathrm{V}$ and $\mathrm{Au}$ ) with their mass concentrations lower than during the precipitation events, indicating a potential longlasting aftereffect of precipitation scavenging. Among all elemental species, the mass concentrations of $\mathrm{Zn}$ and Se fluctuate as a most ideal V-shape, which properly reflects the cycle of precipitation. However, as shown in Fig. 9b, a linear relationship cannot be observed between the decrease rate of the $\mathrm{Zn}$ concentration and the rainfall amount of each precipitation event. Although we failed to pinpoint the exact value in this study, our results imply that there is a threshold of precipitation amount to lower the ambient $\mathrm{PM}_{2.5}$ trace elements mass.

\subsubsection{Change of mass concentration by sources}

The variation of the overall mass concentration of trace elements contributed by each source and their relative contributions before, during and after the total of 12 precipitation events is shown in Fig. 10a to e and f, respectively. The mass concentration of traffic-related trace elements experienced the sharpest decrease during the transition of no-rainy hours to rainy hours $(159 \%)$, and a moderate rebound after precipitation (35\%). Fang et al. (2015) found that mobile source emissions generated through mechanical processes (re-entrained road dust, tire and break wear) and processing by secondary sulfate were major contributors to watersoluble metals. In our study, traffic-related sources mainly include road dust and brake wear, which can not only be easily removed through precipitation but also can hardly be blown up from wet road surfaces after raining. In comparison, the mass contribution of the coal combustion source was also wet removed rapidly first (139\%) due to its tracer elements like $\mathrm{As}, \mathrm{Se}, \mathrm{Pb}$ and $\mathrm{Hg}$ having a larger water-soluble fraction. However, after precipitation, the contribution of the coal combustion source dramatically increased over 2 times (Fig. 10d and f). This can be explained that different from the traffic-related source, the coal combustion-related trace elements are generally emitted through elevated chimneys in the sectors of industrial broilers and power plants. The mass concentrations of trace elements contributed by nonferrous and ferrous metal smelting during the three periods remained quite flat (Fig. 10c and d), suggesting that precipitation has little effect on ambient trace elements emitted from metal smelting activities. Nevertheless, given that traffic-related and coal combustion are the dominant contributors to ambient $\mathrm{PM}_{2.5}$ trace elements, our results validate that water spray could be an effective approach to help curb the severe atmospheric metal pollution in many Chinese cities.

In Fig. 10b and $\mathrm{f}$, the contribution of shipping emissions to ambient trace elements (mainly $\mathrm{V}$ and $\mathrm{Ni}$ ) during the three periods reduced continuously. Mostly transported from the Eastern China sea, V and Ni almost exclusively originated from the east of the sampling site. In other words, the contribution of shipping emissions to the urban atmosphere is supposed to be very sensitive to wind speed and wind direction in Shanghai. The wind roses for the three periods are presented in Fig. 11. It shows that before precipitation events, the average wind speed $( \pm 1 \sigma)$ was the lowest $\left(2.3 \pm 1.3 \mathrm{~m} \mathrm{~s}^{-1}\right)$, and easterly winds prevail in most times. These factors are favorable to the transportation of shipping emissions from the Eastern China sea which then accumulated in the Shanghai urban atmosphere. In contrast to the period before precipitation events, the average wind speed after precipitation events was the highest $\left(3.1 \pm 2.1 \mathrm{~m} \mathrm{~s}^{-1}\right)$ with northwesterly and northerly winds from mainland China which can dilute shipping-related trace elements to the lowest levels (Fig. 10b). In brief, the mass concentration of shipping-related trace elements in the Shanghai urban atmosphere is more likely to be influenced by winds instead of precipitation. 

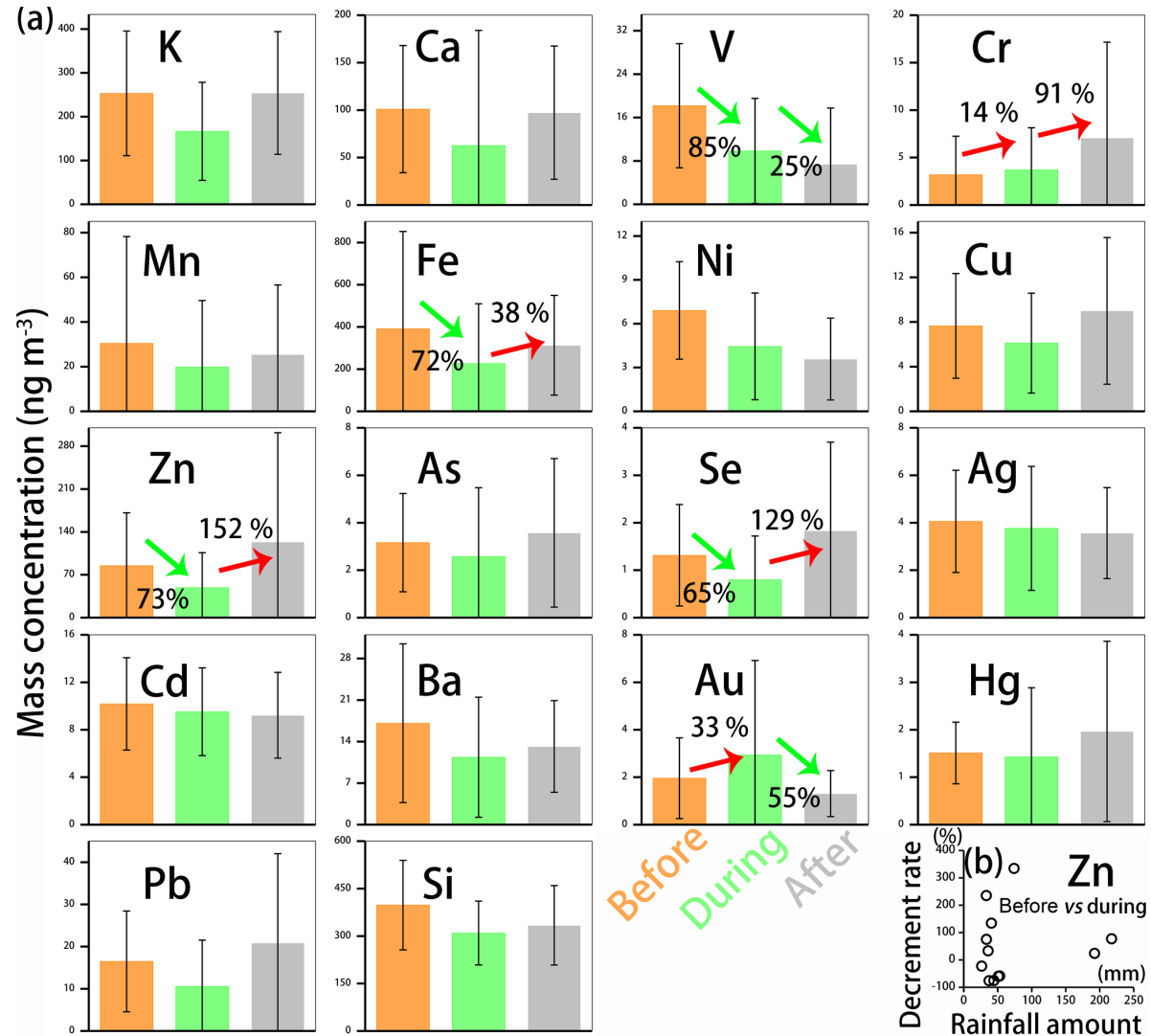

Figure 9. (a) Variation of the overall mass concentration of each elemental species before, during and after the total 12 precipitation events; (b) scatter plot of the relationship between the rainfall amount of each precipitation event and the decrease rate of the $\mathrm{Zn}$ concentration from the period before precipitation to the period after precipitation.
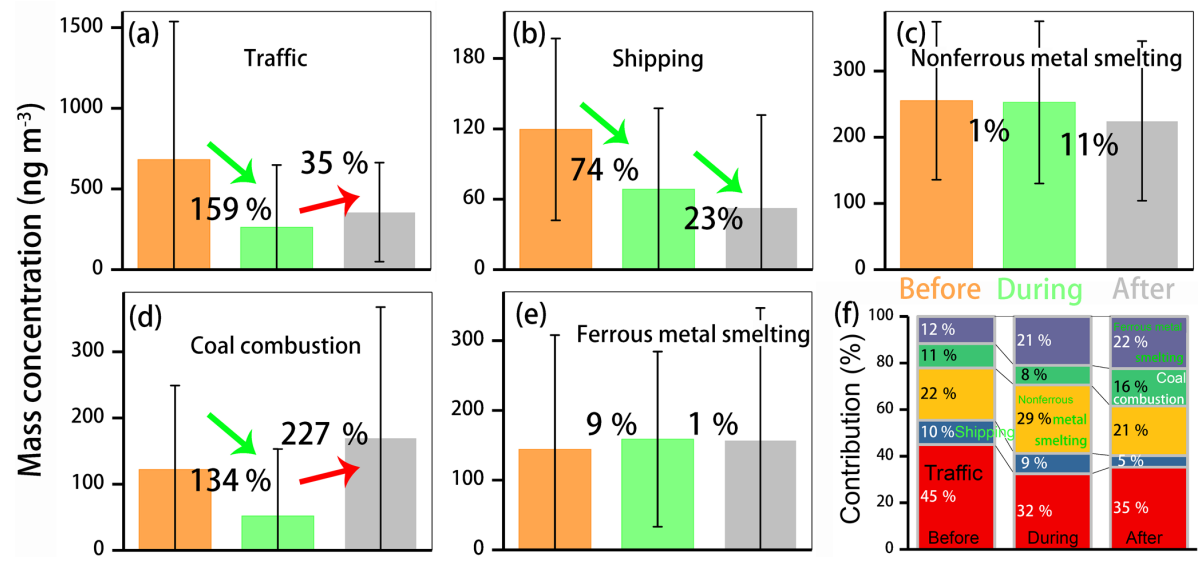

Figure 10. Variation of the overall mass concentration of trace elements contributed by traffic-related (a), shipping (b), nonferrous metal smelting (c), coal combustion (d) and ferrous metal smelting (e); and their relative contributions (f) before, during and after the total 12 precipitation events. 


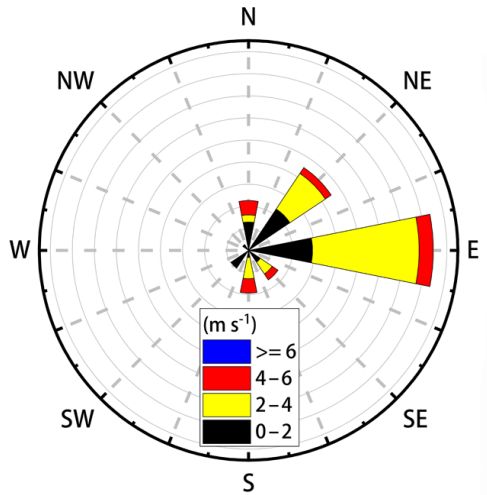

Before $\left(2.3 \pm 1.3 \mathrm{~m} \mathrm{~s}^{-1}\right)$

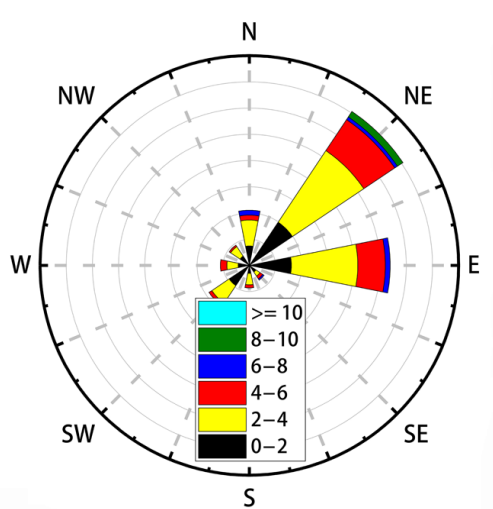

During $\left(2.8 \pm 1.6 \mathrm{~m} \mathrm{~s}^{-1}\right)$

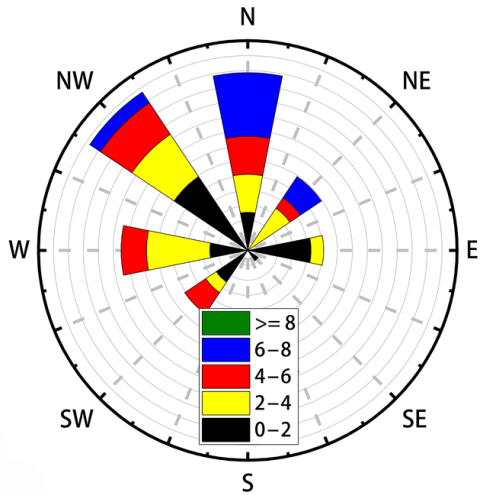

After $\left(3.1 \pm 2.1 \mathrm{~m} \mathrm{~s}^{-1}\right)$

Figure 11. Wind roses for the periods before, during and after the 12 precipitation events. The average wind speed $( \pm 1 \sigma)$ for each period is shown in parentheses.

\section{Conclusion and outlook}

This paper presents the results from a year-long, near realtime measurement study of 18 trace elements ( $\mathrm{Si}, \mathrm{Fe}, \mathrm{K}, \mathrm{Ca}$, $\mathrm{Zn}, \mathrm{Mn}, \mathrm{Pb}, \mathrm{Ba}, \mathrm{V}, \mathrm{Cu}, \mathrm{Cd}, \mathrm{As}, \mathrm{Ni}, \mathrm{Cr}, \mathrm{Ag}, \mathrm{Se}, \mathrm{Hg}$ and $\mathrm{Au}$ ) in $\mathrm{PM}_{2.5}$ using a Xact multi-metals monitor, conducted at an urban site in Shanghai from March 2016 to February 2017. The scientific significance of this work can be reflected by the general findings as follows.

- The Xact multi-metals monitor was demonstrated as a valuable and practical tool for ambient monitoring of atmospheric trace elements by comparing online monitoring results with ICP analyses of offline filter samples.

- The metal concentrations in Shanghai are one or two orders of magnitude higher than in North America and Europe, highlighting the need to allocate more scientific, technical and legal resources on controlling metal emissions in China.

- The total of the metal related species amounted to approximately $8.3 \%$ of the $\mathrm{PM}_{2.5}$ mass, which should not be ignored in China's recent epidemiologic study of attributing hospital emergency-room visits to $\mathrm{PM}_{2.5}$ chemical constituents.

- The full coverage of trace elemental species (18) and the high temporal frequency (hourly) in the work provided unprecedented details regarding the temporal evolution of metal pollution and its potential sources in Shanghai.

- Five sources, i.e., traffic-related, shipping, nonferrous metal smelting, coal combustion and ferrous metal smelting were identified by PMF analysis, which contributed to $46 \%, 6 \%, 15 \%, 18 \%$ and $15 \%$ of the ambient $\mathrm{PM}_{2.5}$ trace elements, respectively.

- The dominant contributors of trace elements (trafficrelated and coal combustion) can be effectively removed through precipitation from the atmosphere, suggesting that water spray can be used to curb $\mathrm{PM}_{2.5}$ trace elements in the urban atmosphere.

A greater value and more interesting topic to the scientific community would be to fully assess the role of $\mathrm{PM}_{2.5}$ chemical constituents (including metal species) and emission sources to human health. Looking towards the future, three major steps will be taken toward thoroughly addressing these questions. Firstly, characterizing the chemical and isotopic (including metal species) signatures of emission sources will be intensively undertaken through field sampling as well as for laboratory simulations (see example of Geagea et al., 2007). Secondly, the Xact multi-metals monitor, Sunset OC / EC analyzer (Chang et al., 2017) and MARGA (Monitoring of AeRosols and Gases) platform will be collocated across a rural-urban-background transect to simultaneously measure hourly metal species, carbonaceous aerosols and inorganic aerosol components in $\mathrm{PM}_{2.5}$. Lastly, integrating all available information regarding $\mathrm{PM}_{2.5}$ chemical species and isotopes into a receptor model or atmospheric chemical transport model will be carried forward to create more specific and confident source apportionment results.

Data availability. Data are available from the corresponding authors on request.

Supplement. The supplement related to this article is available online at: https://doi.org/10.5194/acp-18-11793-2018-supplement.

Author contributions. YZ and YC conceived the study; YC and ZZ designed the experimental strategy and performed the trace elemental measurements; YC, MX, YZ, KH, and CD analyzed the experimental data and constructed the model; YC and $\mathrm{YZ}$ proposed the hypotheses; YC wrote the manuscript with YZ; all other co-authors contributed to the data interpretation and writing. 
Competing interests. The authors declare that they have no competing interests.

Acknowledgements. This study was supported by the National Key Research and Development Program of China (2017YFC0212704), the National Natural Science Foundation of China (Grant nos. 41705100, 91644103, 41603104, 41429501 and 91644105), Provincial Natural Science Foundation of Jiangsu (BK20170946), University Science Research Project of Jiangsu Province (17KJB170011), the Priority Academic Program Development of Jiangsu Higher Education Institutions (PAPD) and the open funding (publication fee) of the International Joint Laboratory on Climate and Environment Change (ILCEC) and the Collaborative Innovation Center on Forecast and Evaluation of Meteorological Disasters (CIC-FEMD) through NUIST. Many thanks go to Tony Dore at the Centre for Ecology and Hydrology, Edinburgh, United Kingdom for his linguistic corrections.

Edited by: Willy Maenhaut

Reviewed by: Tony Dore, Markus Furger and four anonymous referees

\section{References}

Amato, F., Pandolfi, M., Escrig, A., Querol, X., Alastuey, A., Pey, J., Perez, N., and Hopke, P. K.: Quantifying road dust resuspension in urban environment by Multilinear Engine: A comparison with PMF2, Atmos. Environ., 43, 2770-2780, https://doi.org/10.1016/j.atmosenv.2009.02.039, 2009.

Amato, F., Schaap, M., Denier van der Gon, H. A. C., Pandolfi, M., Alastuey, A., Keuken, M., and Querol, X.: Shortterm variability of mineral dust, metals and carbon emission from road dust resuspension, Atmos. Environ., 74, 134-140, https://doi.org/10.1016/j.atmosenv.2013.03.037, 2013.

Brandt, C. and van Eldik, R.: Transition metal-catalyzed oxidation of sulfur (IV) oxides. Atmospheric-relevant processes and mechanisms, Chem. Rev., 95, 119-190, https://doi.org/10.1021/cr00033a006, 1995.

Brown, S. G., Eberly, S., Paatero, P., and Norris, G. A.: Methods for estimating uncertainty in PMF solutions: Examples with ambient air and water quality data and guidance on reporting PMF results, Sci. Total Environ., 518-519, 626-635, https://doi.org/10.1016/j.scitotenv.2015.01.022, 2015.

Bukowiecki, N., Hill, M., Gehrig, R., Zwicky, C. N., Lienemann, P., Hegedüs, F., Falkenberg, G., Weingartner, E., and Baltensperger, U.: Trace metals in ambient air: Hourly size-segregated mass concentrations determined by synchrotron-XRF, Environ. Sci. Technol., 39, 5754-5762, https://doi.org/10.1021/es048089m, 2005.

Bukowiecki, N., Lienemann, P., Hill, M., Furger, M., Richard, A., Amato, F., Prévôt, A. S. H., Baltensperger, U., Buchmann, B., and Gehrig, R.: $\mathrm{PM}_{10}$ emission factors for non-exhaust particles generated by road traffic in an urban street canyon and along a freeway in Switzerland, Atmos. Environ., 44, 23302340, https://doi.org/10.1016/j.atmosenv.2010.03.039, 2010.

Burnett, R. T., Pope III, C. A., Ezzati, M., Olives, C., Lim, S. S., Mehta, S., Shin, H. H., Singh, G., Hubbell, B., Brauer, M., An- derson, H. R., Smith, K. R., Balmes, J. R., Bruce, N. G., Kan, H., Laden, F., Pruss-Ustun, A., Turner, M. C., Gapstur, S. M., Diver, W. R., and Cohen, A.: An integrated risk function for estimating the global burden of disease attributable to ambient fine particulate matter exposure, Environ. Health Perspect., 122, 397-403, https://doi.org/10.1289/ehp.1307049, 2014.

Carslaw, D. C. and Ropkins, K.: Openair - An R package for air quality data analysis, Environ. Modell. Softw., 27-28, 52-61, https://doi.org/10.1016/j.envsoft.2011.09.008, 2012.

Carslaw, D. C., Beevers, S. D., Ropkins, K., and Bell, M. C.: Detecting and quantifying aircraft and other on-airport contributions to ambient nitrogen oxides in the vicinity of a large international airport, Atmos. Environ., 40, 5424-5434, https://doi.org/10.1016/j.atmosenv.2006.04.062, 2006.

Cate, D. M., Noblitt, S. D., Volckens, J., and Henry, C. S.: Multiplexed paper analytical device for quantification of metals using distance-based detection, Lab Chip, 15, 2808-2818, https://doi.org/10.1039/c5lc00364d, 2015.

Celo, V., Dabek-Zlotorzynska, E., and McCurdy, M.: Chemical characterization of exhaust emissions from selected Canadian marine vessels: the case of trace metals and lanthanoids, Environ. Sci. Technol., 49, 5220-5226, https://doi.org/10.1021/acs.est.5b00127, 2015.

Cesari, D., Genga, A., Ielpo, P., Siciliano, M., Mascolo, G., Grasso, F. M., and Contini, D.: Source apportionment of $\mathrm{PM}_{2.5}$ in the harbour-industrial area of Brindisi (Italy): Identification and estimation of the contribution of inport ship emissions, Sci. Total Environ., 497-498, 392-400, https://doi.org/10.1016/j.scitotenv.2014.08.007, 2014.

Chang, Y., Zou, Z., Deng, C., Huang, K., Collett, J. L., Lin, J., and Zhuang, G.: The importance of vehicle emissions as a source of atmospheric ammonia in the megacity of Shanghai, Atmos. Chem. Phys., 16, 3577-3594, https://doi.org/10.5194/acp16-3577-2016, 2016.

Chang, Y., Deng, C., Cao, F., Cao, C., Zou, Z., Liu, S., Lee, X., Li, J., Zhang, G., and Zhang, Y.: Assessment of carbonaceous aerosols in Shanghai, China - Part 1: long-term evolution, seasonal variations, and meteorological effects, Atmos. Chem. Phys., 17, 9945-9964, https://doi.org/10.5194/acp-179945-2017, 2017.

Charrier, J. G. and Anastasio, C.: On dithiothreitol (DTT) as a measure of oxidative potential for ambient particles: evidence for the importance of soluble transition metals, Atmos. Chem. Phys., 12, 9321-9333, https://doi.org/10.5194/acp-12-9321-2012, 2012.

Chen, B., Stein, A. F., Castell, N., Gonzalez-Castanedo, Y., Sanchez de la Campa, A. M., and de la Rosa, J. D.: Modeling and evaluation of urban pollution events of atmospheric heavy metals from a large Cu-smelter, Sci. Total Environ., 539, 17-25, https://doi.org/10.1016/j.scitotenv.2015.08.117, 2016.

Chen, L. W. A., Watson, J. G., Chow, J. C., and Magliano, K. L.: Quantifying $\mathrm{PM}_{2.5}$ source contributions for the San Joaquin Valley with multivariate receptor models, Environ. Sci. Technol., 41, 2818-2826, https://doi.org/10.1021/es0525105, 2007.

Cooper, J. A., Petterson, K., Geiger, A., Siemers, A., and Rupprecht, B.: Guide for developing a multi-metals, fenceline monitoring plan for fugitive emissions using X-ray based monitors, Cooper Environmental Services, Portland, Oregon, 1-42, 2010.

Dabek-Zlotorzynska, E., Dann, T. F., Kalyani Martinelango, P., Celo, V., Brook, J. R., Mathieu, D., Ding, L., and Austin, C. 
C.: Canadian National Air Pollution Surveillance (NAPS) $\mathrm{PM}_{2.5}$ speciation program: Methodology and $\mathrm{PM}_{2.5}$ chemical composition for the years 2003-2008, Atmos. Environ., 45, 673-686, https://doi.org/10.1016/j.atmosenv.2010.10.024, 2011.

Dall'Osto, M., Querol, X., Amato, F., Karanasiou, A., Lucarelli, F., Nava, S., Calzolai, G., and Chiari, M.: Hourly elemental concentrations in $\mathrm{PM}_{2.5}$ aerosols sampled simultaneously at urban background and road site during SAPUSS - diurnal variations and PMF receptor modelling, Atmos. Chem. Phys., 13, 43754392, https://doi.org/10.5194/acp-13-4375-2013, 2013.

Dall'Osto, M., Beddows, D. C. S., Harrison, R. M., and Onat, B.: Fine iron aerosols are internally mixed with nitrate in the urban European atmosphere, Environ. Sci. Technol., 50, 4212-4220, https://doi.org/10.1021/acs.est.6b01127, 2016.

DeCarlo, P. F., Kimmel, J. R., Trimborn, A., Northway, M. J., Jayne, J. T., Aiken, A. C., Gonin, M., Fuhrer, K., Horvath, T., Docherty, K. S., Worsnop, D. R., and Jimenez, J. L.: Field-deployable, high-resolution, time-of-flight aerosol mass spectrometer, Anal. Chem., 78, 8281-8289, https://doi.org/10.1021/ac061249n, 2006.

Duan, J. and Tan, J.: Atmospheric heavy metals and arsenic in China: Situation, sources and control policies, Atmos. Environ., 74, 93-101, https://doi.org/10.1016/j.atmosenv.2013.03.031, 2013.

Duce, R. A. and Hoffman, G. L.: Atmospheric vanadium transport to the ocean, Atmos. Environ., 10, 989-996, https://doi.org/10.1016/0004-6981(76)90207-9, 1976.

Fan, Q., Zhang, Y., Ma, W., Ma, H., Feng, J., Yu, Q., Yang, X., Ng, S. K. W., Fu, Q., and Chen, L.: Spatial and seasonal dynamics of ship emissions over the Yangtze River Delta and East China Sea and their potential environmental influence, Environ. Sci. Technol., 50, 1322-1329, https://doi.org/10.1021/acs.est.5b03965, 2016.

Fang, T., Guo, H., Verma, V., Peltier, R. E., and Weber, R. J.: $\mathrm{PM}_{2.5}$ water-soluble elements in the southeastern United States: automated analytical method development, spatiotemporal distributions, source apportionment, and implications for heath studies, Atmos. Chem. Phys., 15, 11667-11682, https://doi.org/10.5194/acp-15-11667-2015, 2015.

Fergusson, J. E.: The heavy elements: Chemistry, environmental impact and health effects, Pergamon Press, Oxford, UK, 614 pp., 1990.

Furger, M., Minguillón, M. C., Yadav, V., Slowik, J. G., Hüglin, C., Fröhlich, R., Petterson, K., Baltensperger, U., and Prévôt, A. S. H.: Elemental composition of ambient aerosols measured with high temporal resolution using an online XRF spectrometer, Atmos. Meas. Tech., 10, 2061-2076, https://doi.org/10.5194/amt10-2061-2017, 2017.

Geagea, M. L., Stille, P., Millet, M., and Perrone, T.: REE characteristics and $\mathrm{Pb}, \mathrm{Sr}$ and $\mathrm{Nd}$ isotopic compositions of steel plant emissions, Sci. Total Environ., 373, 404-419, https://doi.org/10.1016/j.scitotenv.2006.11.011, 2007.

Gross, D. S., Gälli, M. E., Silva, P. J., and Prather, K. A.: Relative sensitivity factors for alkali metal and ammonium cations in single-particle aerosol time-of-flight mass spectra, Anal. Chem., 72, 416-422, https://doi.org/10.1021/ac990434g, 2000.

Han, T., Qiao, L., Zhou, M., Qu, Y., Du, J., Liu, X., Lou, S., Chen, C., Wang, H., Zhang, F., Yu, Q., and Wu, Q.: Chemical and optical properties of aerosols and their interrelationship in winter in the megacity Shanghai of China, J. Environ. Sci., 27, 59-69, https://doi.org/10.1016/j.jes.2014.04.018, 2015.

Harrison, R. M., Jones, A. M., Gietl, J., Yin, J., and Green, D. C.: Estimation of the contributions of brake dust, tire wear, and resuspension to nonexhaust traffic particles derived from atmospheric measurements, Environ. Sci. Technol., 46, 6523-6529, https://doi.org/10.1021/es300894r, 2012.

Healy, R. M., Hellebust, S., Kourtchev, I., Allanic, A., O’Connor, I. P., Bell, J. M., Healy, D. A., Sodeau, J. R., and Wenger, J. C.: Source apportionment of $\mathrm{PM}_{2.5}$ in Cork Harbour, Ireland using a combination of single particle mass spectrometry and quantitative semi-continuous measurements, Atmos. Chem. Phys., 10, 9593-9613, https://doi.org/10.5194/acp-10-9593-2010, 2010.

Hjortenkrans, D. S. T., Bergbäck, B. G., and Häggerud, A. V.: Metal emissions from brake linings and tires: Case studies of Stockholm, Sweden 1995/1998 and 2005, Environ. Sci. Technol., 41, 5224-5230, https://doi.org/10.1021/es070198o, 2007.

Holden, P. A., Gardea-Torresdey, J. L., Klaessig, F., Turco, R. F., Mortimer, M., Hund-Rinke, K., Cohen Hubal, E. A., Avery, D., Barceló, D., Behra, R., Cohen, Y., Deydier-Stephan, L., Ferguson, P. L., Fernandes, T. F., Herr Harthorn, B., Henderson, W. M., Hoke, R. A., Hristozov, D., Johnston, J. M., Kane, A. B., Kapustka, L., Keller, A. A., Lenihan, H. S., Lovell, W., Murphy, C. J., Nisbet, R. M., Petersen, E. J., Salinas, E. R., Scheringer, M., Sharma, M., Speed, D. E., Sultan, Y., Westerhoff, P., White, J. C., Wiesner, M. R., Wong, E. M., Xing, B., Steele Horan, M., Godwin, H. A., and Nel, A. E.: Considerations of environmentally relevant test conditions for improved evaluation of ecological hazards of engineered nanomaterials, Environ. Sci. Technol., 50, 6124-6145, https://doi.org/10.1021/acs.est.6b00608, 2016.

Honda, T., Eliot, M. N., Eaton, C. B., Whitsel, E., Stewart, J. D., Mu, L., Suh, H., Szpiro, A., Kaufman, J. D., Vedal, S., and Wellenius, G. A.: Long-term exposure to residential ambient fine and coarse particulate matter and incident hypertension in post-menopausal women, Environ. Int., 105, 79-85, https://doi.org/10.1016/j.envint.2017.05.009, 2017.

Hu, X., Zhang, Y., Ding, Z., Wang, T., Lian, H., Sun, Y., and $\mathrm{Wu}, \mathrm{J}$.: Bioaccessibility and health risk of arsenic and heavy metals ( $\mathrm{Cd}, \mathrm{Co}, \mathrm{Cr}, \mathrm{Cu}, \mathrm{Ni}, \mathrm{Pb}, \mathrm{Zn}$ and $\mathrm{Mn}$ ) in TSP and $\mathrm{PM}_{2.5}$ in Nanjing, China, Atmos. Environ., 57, 146-152, https://doi.org/10.1016/j.atmosenv.2012.04.056, 2012.

Huang, C., Chen, C. H., Li, L., Cheng, Z., Wang, H. L., Huang, H. Y., Streets, D. G., Wang, Y. J., Zhang, G. F., and Chen, Y. R.: Emission inventory of anthropogenic air pollutants and VOC species in the Yangtze River Delta region, China, Atmos. Chem. Phys., 11, 4105-4120, https://doi.org/10.5194/acp11-4105-2011, 2011.

Huang, K., Zhuang, G., Lin, Y., Wang, Q., Fu, J. S., Fu, Q., Liu, T., and Deng, C.: How to improve the air quality over megacities in China: pollution characterization and source analysis in Shanghai before, during, and after the 2010 World Expo, Atmos. Chem. Phys., 13, 5927-5942, https://doi.org/10.5194/acp13-5927-2013, 2013.

Huang, W., Cao, J., Tao, Y., Dai, L., Lu, S.-E., Hou, B., Wang, Z., and Zhu, T.: Seasonal variation of chemical species associated with short-term mortality effects of $\mathrm{PM}_{2.5}$ in $\mathrm{Xi}$ 'an, a central city in China, Am. J. Epidemiol., 175, 556-566, https://doi.org/10.1093/aje/kwr342, 2012. 
Hueglin, C., Gehrig, R., Baltensperger, U., Gysel, M., Monn, C., and Vonmont, H.: Chemical characterisation of $\mathrm{PM}_{2.5}$, $\mathrm{PM}_{10}$ and coarse particles at urban, near-city and rural sites in Switzerland, Atmos. Environ., 39, 637-651, https://doi.org/10.1016/j.atmosenv.2004.10.027, 2005.

Hope, B. K.: A global biogeochemical budget for vanadium, Sci. Total Environ., 141, 1-10, https://doi.org/10.1016/00489697(94)90012-4, 1994

Iyengar, V. and Woittiez, J.: Trace elements in human clinical specimens: evaluation of literature data to identify reference values, Clin. Chem., 34, 474-481, 1988.

Jeong, C.-H., Wang, J. M., and Evans, G. J.: Source Apportionment of Urban Particulate Matter using Hourly Resolved Trace Metals, Organics, and Inorganic Aerosol Components, Atmos. Chem. Phys. Discuss., https://doi.org/10.5194/acp-2016-189, 2016.

John, D. H.: "Heavy metals"-a meaningless term?, Pure Appl. Chem., 74, 793-807, https://doi.org/10.1351/pac200274050793, 2002.

Jomova, K. and Valko, M.: Advances in metal-induced oxidative stress and human disease, Toxicol., 283, 65-87, https://doi.org/10.1016/j.tox.2011.03.001, 2011.

Karanasiou, A.: Road dust emission sources and assessment of street washing effect, Aerosol Air Qual. Res., 14, 734-743, https://doi.org/10.4209/aaqr.2013.03.0074, 2014.

Karanasiou, A., Moreno, T., Amato, F., Lumbreras, J., Narros, A., Borge, R., Tobías, A., Boldo, E., Linares, C., Pey, J., Reche, C., Alastuey, A., and Querol, X.: Road dust contribution to PM levels - Evaluation of the effectiveness of street washing activities by means of Positive Matrix Factorization, Atmos. Environ., 45, 2193-2201, https://doi.org/10.1016/j.atmosenv.2011.01.067, 2011.

Karanasiou, A., Moreno, T., Amato, F., Tobías, A., Boldo, E., Linares, C., Lumbreras, J., Borge, R., Alastuey, A., and Querol, X.: Variation of $\mathrm{PM}_{2.5}$ concentrations in relation to street washing activities, Atmos. Environ., 54, 465-469, https://doi.org/10.1016/j.atmosenv.2012.02.006, 2012.

Kastury, F., Smith, E., and Juhasz, A. L.: A critical review of approaches and limitations of inhalation bioavailability and bioaccessibility of metal(loid)s from ambient particulate matter or dust, Sci. Total Environ., 574, 1054-1074, https://doi.org/10.1016/j.scitotenv.2016.09.056, 2017.

Kim, E. and Hopke, P. K.: Comparison between samplespecies specific uncertainties and estimated uncertainties for the source apportionment of the speciation trends network data, Atmos. Environ., 41, 567-575, https://doi.org/10.1016/j.atmosenv.2006.08.023, 2007.

Kim, E., Hopke, P. K., and Qin, Y.: Estimation of organic carbon blank values and error structures of the speciation trends network data for source apportionment, J. Air Waste Manage. Assoc., 55, 1190-1199, https://doi.org/10.1080/10473289.2005.10464705, 2005.

Kim, K. H., Kabir, E., and Jahan, S. A.: A review on the distribution of $\mathrm{Hg}$ in the environment and its human health impacts, J. Hazard. Mater., 306, 376-385, https://doi.org/10.1016/j.jhazmat.2015.11.031, 2016.

Kloog, I., Ridgway, B., Koutrakis, P., Coull, B. A., and Schwartz, J. D.: Long- and short-term exposure to $\mathrm{PM}_{2.5}$ and mortality: Using novel exposure models, Epidemiol., 24, 555-561, https://doi.org/10.1097/EDE.0b013e318294beaa, 2013.
Kuhns, H., Etyemezian, V., Green, M., Hendrickson, K., McGown, M., Barton, K., and Pitchford, M.: Vehicle-based road dust emission measurement-Part II: Effect of precipitation, wintertime road sanding, and street sweepers on inferred $\mathrm{PM}_{10}$ emission potentials from paved and unpaved roads, Atmos. Environ., 37, 4573-4582, https://doi.org/10.1016/S1352-2310(03)005296, 2003.

Leung, A. O. W., Duzgoren-Aydin, N. S., Cheung, K. C., and Wong, M. H.: Heavy metals concentrations of surface dust from e-waste recycling and its human health implications in Southeast China, Environ. Sci. Technol., 42, 2674-2680, https://doi.org/10.1021/es071873x, 2008.

Li, H., Wang, J., Wang, Q., Tian, C., Qian, X., and Leng, X.: Magnetic properties as a proxy for predicting fineparticle-bound heavy metals in a support vector machine approach, Environ. Sci. Technol., 51, 6927-6935, https://doi.org/10.1021/acs.est.7b00729, 2017.

Lin, Y.-C., Tsai, C.-J., Wu, Y.-C., Zhang, R., Chi, K.-H., Huang, Y.-T., Lin, S.-H., and Hsu, S.-C.: Characteristics of trace metals in traffic-derived particles in Hsuehshan Tunnel, Taiwan: size distribution, potential source, and fingerprinting metal ratio, Atmos. Chem. Phys., 15, 4117-4130, https://doi.org/10.5194/acp15-4117-2015, 2015.

Litter, M. I.: Heterogeneous photocatalysis: Transition metal ions in photocatalytic systems, Appl. Catal. B-Environ., 23, 89-114, https://doi.org/10.1016/S0926-3373(99)00069-7, 1999.

Liu, S., Triantis, K., and Zhang, L.: The design of an urban roadside automatic sprinkling system: mitigation of $\mathrm{PM}_{2.5-10}$ in ambient air in megacities, Chinese J. Engineering, 12, https://doi.org/10.1155/2014/618109, 2014.

Liu, Z., Hu, B., Wang, L., Wu, F., Gao, W., and Wang, Y.: Seasonal and diurnal variation in particulate matter $\left(\mathrm{PM}_{10}\right.$ and $\mathrm{PM}_{2.5}$ ) at an urban site of Beijing: Analyses from a 9-year study, Environ. Sci. Pollut. Res. Int., 22, 627-642, https://doi.org/10.1007/s11356-014-3347-0, 2015.

Liu, Z., Lu, X., Feng, J., Fan, Q., Zhang, Y., and Yang, X.: Influence of ship emissions on urban air quality: A comprehensive study using highly time-resolved online measurements and numerical simulation in Shanghai, Environ. Sci. Technol., 51, 202211, https://doi.org/10.1021/acs.est.6b03834, 2017.

Lough, G. C., Schauer, J. J., Park, J. S., Shafer, M. M., DeMinter, J. T., and Weinstein, J. P.: Emissions of metals associated with motor vehicle roadways, Environ. Sci. Technol., 39, 826-836, https://doi.org/10.1021/es048715f, 2005.

Lu, S., Yao, Z., Chen, X., Wu, M., Sheng, G., Fu, J., and Paul, D.: The relationship between physicochemical characterization and the potential toxicity of fine particulates $\left(\mathrm{PM}_{2.5}\right)$ in Shanghai atmosphere, Atmos. Environ., 42, 7205-7214, https://doi.org/10.1016/j.atmosenv.2008.07.030, 2008.

Maenhaut, W.: Present role of PIXE in atmospheric aerosol research, Nucl. Instrum. Meth. B, 363, 86-91, https://doi.org/10.1016/j.nimb.2015.07.043, 2015.

Morawska, L. and Zhang, J.: Combustion sources of particles. 1. Health relevance and source signatures, Chemos., 49, 10451058, https://doi.org/10.1016/S0045-6535(02)00241-2, 2002.

Morman, S. A. and Plumlee, G. S.: The role of airborne mineral dusts in human disease, Aeolian Res., 9, 203-212, https://doi.org/10.1016/j.aeolia.2012.12.001, 2013. 
Murphy, D. M., Thomson, D. S., and Mahoney, M. J.: In situ measurements of organics, meteoritic material, mercury, and other elements in aerosols at 5 to 19 kilometers, Science, 282, 16641669, https://doi.org/10.1126/science.282.5394.1664, 1998.

Normile, D.: China's living laboratory in urbanization, Science, 319, 740-743, https://doi.org/10.1126/science.319.5864.740, 2008.

Norris, G., Duvall, R., Brown, S., and Bai, S.: EPA Positive Matrix Factorization (PMF) 5.0 fundamentals and user guide prepared for the US Environmental Protection Agency Office of Research and Development, Washington, DC, 2014.

Olujimi, O. O., Oputu, O., Fatoki, O., Opatoyinbo, O. E., Aroyewun, O. A., and Baruani, J.: Heavy metals speciation and human health risk assessment at an illegal gold mining site in Igun, Osun State, Nigeria, J. Heal. Pollut., 5, 19-32, https://doi.org/10.5696/i2156-9614-5-8.19, 2015.

Paatero, P. and Tapper, U.: Positive matrix factorization: A non-negative factor model with optimal utilization of error estimates of data values, Environmetrics, 5, 111-126, https://doi.org/10.1002/env.3170050203, 1994.

Paatero, P., Eberly, S., Brown, S. G., and Norris, G. A.: Methods for estimating uncertainty in factor analytic solutions, Atmos. Meas. Tech., 7, 781-797, https://doi.org/10.5194/amt-7781-2014, 2014.

Pacyna, J. M. and Pacyna, E. G.: An assessment of global and regional emissions of trace metals to the atmosphere from anthropogenic sources worldwide, Environ. Rev., 9, 269-298, https://doi.org/10.1139/a01-012, 2001.

Pardo, M., Shafer, M. M., Rudich, A., Schauer, J. J., and Rudich, Y.: Single exposure to near roadway particulate matter leads to confined inflammatory and defense responses: Possible role of metals, Environ. Sci. Technol., 49, 8777-8785, https://doi.org/10.1021/acs.est.5b01449, 2015.

Park, S. S., Cho, S. Y., Jo, M. R., Gong, B. J., Park, J. S., and Lee, S. J.: Field evaluation of a near-real time elemental monitor and identification of element sources observed at an air monitoring supersite in Korea, Atmos. Pollut. Res., 5, 119-128, https://doi.org/10.5094/apr.2014.015, 2014.

Perry, K. D., Cahill, T. A., Schnell, R. C., and Harris, J. M.: Long-range transport of anthropogenic aerosols to the National Oceanic and Atmospheric Administration baseline station at Mauna Loa Observatory, Hawaii, J. Geophys. Res., 104, 1852118533, https://doi.org/10.1029/1998JD100083, 1999.

Phillips-Smith, C., Jeong, C.-H., Healy, R. M., DabekZlotorzynska, E., Celo, V., Brook, J. R., and Evans, G.: Sources of particulate matter components in the Athabasca oil sands region: investigation through a comparison of trace element measurement methodologies, Atmos. Chem. Phys., 17, 9435-9449, https://doi.org/10.5194/acp-17-9435-2017, 2017.

Polissar, V., Hopke, P., Paatero, P., Malm, W., and Sisler, J.: Atmospheric aerosol over Alaska: 2. Elemental composition and sources, J. Geophys. Res., 103, 19045-19057, https://doi.org/10.1029/98JD01212, 1998.

Pope III, C. A., Burnett, R. T., Thun, M. J., Calle, E. E., Krewski, D., Ito, K., and Thurston, G. D.: Lung cancer, cardiopulmonary mortality, and long-term exposure to fine particulate air pollution, J. Am. Med. Assoc., 287, 1132-1141, 2002.

Pope III, C. A., Ezzati, M., and Dockery, D. W.: Fine-particulate air pollution and life expectancy in the United States, New Engl. J.
Med., 360, 376-386, https://doi.org/10.1056/NEJMsa0805646, 2009.

Qiao, L., Cai, J., Wang, H., Wang, W., Zhou, M., Lou, S., Chen, R., Dai, H., Chen, C., and Kan, H.: $\mathrm{PM}_{2.5}$ constituents and hospital emergency-room visits in Shanghai, China, Environ. Sci. Technol., 48, 10406-10414, https://doi.org/10.1021/es501305k, 2014.

Querol, X., Juan, R., Lopez-Soler, A., Fernandez-Turiel, J., and Ruiz, C. R.: Mobility of trace elements from coal and combustion wastes, Fuel, 75, 821-838, https://doi.org/10.1016/00162361(96)00027-0, 1996.

Richard, A., Bukowiecki, N., Lienemann, P., Furger, M., Fierz, M., Minguillón, M. C., Weideli, B., Figi, R., Flechsig, U., Appel, K., Prévôt, A. S. H., and Baltensperger, U.: Quantitative sampling and analysis of trace elements in atmospheric aerosols: impactor characterization and Synchrotron-XRF mass calibration, Atmos. Meas. Tech., 3, 1473-1485, https://doi.org/10.5194/amt-3-14732010, 2010.

Ridley, D. A., Heald, C. L., Kok, J. F., and Zhao, C.: An observationally constrained estimate of global dust aerosol optical depth, Atmos. Chem. Phys., 16, 15097-15117, https://doi.org/10.5194/acp-16-15097-2016, 2016.

Rubasinghege, G., Elzey, S., Baltrusaitis, J., Jayaweera, P. M., and Grassian, V. H.: Reactions on atmospheric dust particles: Surface photochemistry and size-dependent nanoscale redox chemistry, J. Phys. Chem. Let., 1, 1729-1737, https://doi.org/10.1021/jz100371d, 2010a.

Rubasinghege, G., Lentz, R. W., Scherer, M. M., and Grassian, V. H.: Simulated atmospheric processing of iron oxyhydroxide minerals at low $\mathrm{pH}$ : Roles of particle size and acid anion in iron dissolution, P. Natl. Acad. Sci. USA, 107, 6628-6633, https://doi.org/10.1073/pnas.0910809107, 2010b.

Saffari, A., Daher, N., Shafer, M. M., Schauer, J. J., and Sioutas, C.: Global perspective on the oxidative potential of airborne particulate matter: A synthesis of research findings, Environ. Sci. Technol., 48, 7576-7583, https://doi.org/10.1021/es500937x, 2014.

Seigneur, C. and Constantinou, E.: Chemical kinetic mechanism for atmospheric chromium, Environ. Sci. Technol., 29, 222-231, https://doi.org/10.1021/es00001a029, 1995.

Shafer, M. M., Toner, B. M., Overdier, J. T., Schauer, J. J., Fakra, S. C., Hu, S., Herner, J. D., and Ayala, A.: Chemical speciation of vanadium in particulate matter emitted from diesel vehicles and urban atmospheric aerosols, Environ. Sci. Technol., 46, 189-195, https://doi.org/10.1021/es200463c, 2012.

Shah, A. S. V., Langrish, J. P., Nair, H., McAllister, D. A., Hunter, A. L., Donaldson, K., Newby, D. E., and Mills, N. L.: Global association of air pollution and heart failure: A systematic review and meta-analysis, Lancet, 382, 1039-1048, https://doi.org/10.1016/s0140-6736(13)60898-3, 2013.

Shu, J., Dearing, J. A., Morse, A. P., Yu, L., and Yuan, N.: Determining the sources of atmospheric particles in Shanghai, China, from magnetic and geochemical properties, Atmos. Environ., 35, 2615-2625, https://doi.org/10.1016/S1352-2310(00)00454$4,2001$.

Sofowote, U. M., Su, Y., Dabek-Zlotorzynska, E., Rastogi, A. K., Brook, J., and Hopke, P. K.: Sources and temporal variations of constrained PMF factors obtained from multiple-year receptor modeling of ambient $\mathrm{PM}_{2.5}$ data from five specia- 
tion sites in Ontario, Canada, Atmos. Environ., 108, 140-150, https://doi.org/10.1016/j.atmosenv.2015.02.055, 2015.

Strak, M., Janssen, N. A., Godri, K. J., Gosens, I., Mudway, I. S., Cassee, F. R., Lebret, E., Kelly, F. J., Harrison, R. M., Brunekreef, B., Steenhof, M., and Hoek, G.: Respiratory health effects of airborne particulate matter: The role of particle size, composition, and oxidative potential-the RAPTES project, Environ. Health Perspect., 120, 1183-1189, https://doi.org/10.1289/ehp.1104389, 2012.

Streit, B.: Lexikon der Okotoxikologie, Wiley-VCH, Weinheim, Germany, 1991.

Strickland, M. J., Hao, H., Hu, X., Chang, H. H., Darrow, L. A., and Liu, Y.: Pediatric emergency visits and short-term changes in $\mathrm{PM}_{2.5}$ concentrations in the U.S. State of Georgia, Environ. Health Perspect., 124, 690-696, https://doi.org/10.1289/ehp.1509856, 2016.

Suess, D. T.: Single particle mass spectrometry combustion source characterization and atmospheric apportionment of vehicular, coal and biofuel exhaust emissions, $\mathrm{PhD}$, Chemistry, University of California, Riverside, CA, USA, 2002.

Tang, M., Huang, X., Lu, K., Ge, M., Li, Y., Cheng, P., Zhu, T., Ding, A., Zhang, Y., Gligorovski, S., Song, W., Ding, X., Bi, X., and Wang, X.: Heterogeneous reactions of mineral dust aerosol: implications for tropospheric oxidation capacity, Atmos. Chem. Phys., 17, 11727-11777, https://doi.org/10.5194/acp-17-117272017, 2017.

Tao, L., Fairley, D., Kleeman, M. J., and Harley, R. A.: Effects of switching to lower sulfur marine fuel oil on air quality in the San Francisco Bay area, Environ. Sci. Technol., 47, 10171-10178, https://doi.org/10.1021/es401049x, 2013.

Tchounwou, P. B., Yedjou, C. G., Patlolla, A. K., and Sutton, D. J.: Heavy metals toxicity and the environment, in: Molecular, Clinical and Environmental Toxicology, Springer, Basel, Switzerland, 133-164, 2012.

Thorpe, A. and Harrison, R. M.: Sources and properties of non-exhaust particulate matter from road traffic: A review, Sci. Total Environ., 400, 270-282, https://doi.org/10.1016/j.scitotenv.2008.06.007, 2008.

Tian, H. Z., Zhu, C. Y., Gao, J. J., Cheng, K., Hao, J. M., Wang, K., Hua, S. B., Wang, Y., and Zhou, J. R.: Quantitative assessment of atmospheric emissions of toxic heavy metals from anthropogenic sources in China: Historical trend, spatial distribution, uncertainties, and control policies, Atmos. Chem. Phys., 15, 1012710147, https://doi.org/10.5194/acp-15-10127-2015, 2015.

Traversi, R., Becagli, S., Calzolai, G., Chiari, M., Giannoni, M., Lucarelli, F., Nava, S., Rugi, F., Severi, M., and Udisti, R.: A comparison between PIXE and ICP-AES measurements of metals in aerosol particulate collected in urban and marine sites in Italy, Nucl. Instrum. Meth. B, 318, 130-134, https://doi.org/10.1016/j.nimb.2013.05.102, 2014.

Usher, C. R., Michel, A. E., and Grassian, V. H.: Reactions on mineral dust, Chem. Rev., 103, 4883-4940, https://doi.org/10.1021/cr020657y, 2003.

Verma, V., Shafer, M. M., Schauer, J. J., and Sioutas, C.: Contribution of transition metals in the reactive oxygen species activity of PM emissions from retrofitted heavy-duty vehicles, Atmos. Environ., 44, 5165-5173, https://doi.org/10.1016/j.atmosenv.2010.08.052, 2010.
Viana, M., Amato, F., Alastuey, A., Querol, X., Moreno, T., García Dos Santos, S., Herce, M. D., and Fernández-Patier, R.: Chemical tracers of particulate emissions from commercial shipping, Environ. Sci. Technol., 43, 7472-7477, https://doi.org/10.1021/es901558t, 2009.

Visser, S., Slowik, J. G., Furger, M., Zotter, P., Bukowiecki, N., Canonaco, F., Flechsig, U., Appel, K., Green, D. C., Tremper, A. H., Young, D. E., Williams, P. I., Allan, J. D., Coe, H., Williams, L. R., Mohr, C., Xu, L., Ng, N. L., Nemitz, E., Barlow, J. F., Halios, C. H., Fleming, Z. L., Baltensperger, U., and Prévôt, A. S. H.: Advanced source apportionment of size-resolved trace elements at multiple sites in London during winter, Atmos. Chem. Phys., 15, 11291-11309, https://doi.org/10.5194/acp-15-112912015, 2015a.

Visser, S., Slowik, J. G., Furger, M., Zotter, P., Bukowiecki, N., Dressler, R., Flechsig, U., Appel, K., Green, D. C., Tremper, A. H., Young, D. E., Williams, P. I., Allan, J. D., Herndon, S. C., Williams, L. R., Mohr, C., Xu, L., Ng, N. L., Detournay, A., Barlow, J. F., Halios, C. H., Fleming, Z. L., Baltensperger, U., and Prévôt, A. S. H.: Kerb and urban increment of highly time-resolved trace elements in $\mathrm{PM}_{10}, \mathrm{PM}_{2.5}$ and $\mathrm{PM}_{1.0}$ winter aerosol in London during ClearfLo 2012, Atmos. Chem. Phys., 15, 2367-2386, https://doi.org/10.5194/acp15-2367-2015, 2015b.

Wang, F., Chen, Y., Meng, X., Fu, J., and Wang, B.: The contribution of anthropogenic sources to the aerosols over East China Sea, Atmos. Environ., 127, 22-33, https://doi.org/10.1016/j.atmosenv.2015.12.002, 2016.

Wang, J., Hu, Z., Chen, Y., Chen, Z., and Xu, S.: Contamination characteristics and possible sources of $\mathrm{PM}_{10}$ and $\mathrm{PM}_{2.5}$ in different functional areas of Shanghai, China, Atmos. Environ., 68, 221-229, https://doi.org/10.1016/j.atmosenv.2012.10.070, 2013.

Wang, Q., He, X., Huang, X. H. H., Griffith, S. M., Feng, Y., Zhang, T., Zhang, Q., Wu, D., and Yu, J. Z.: Impact of secondary organic aerosol tracers on tracer-based source apportionment of organic carbon and $\mathrm{PM}_{2.5}$ : A case study in the Pearl River Delta, China, ACS Earth Space Chem., 1, 562-571, https://doi.org/10.1021/acsearthspacechem.7b00088, 2017.

Wang, X., Bi, X., Sheng, G., and Fu, J.: Hospital indoor $\mathrm{PM}_{10} / \mathrm{PM}_{2.5}$ and associated trace elements in Guangzhou, China, Sci. Total Environ., 366, 124-135, https://doi.org/10.1016/j.scitotenv.2005.09.004, 2006.

Wang, X., Williams, B. J., Wang, X., Tang, Y., Huang, Y., Kong, L., Yang, X., and Biswas, P.: Characterization of organic aerosol produced during pulverized coal combustion in a drop tube furnace, Atmos. Chem. Phys., 13, 10919-10932, https://doi.org/10.5194/acp-13-10919-2013, 2013.

West, J. J., Cohen, A., Dentener, F., Brunekreef, B., Zhu, T., Armstrong, B., Bell, M. L., Brauer, M., Carmichael, G., Costa, D. L., Dockery, D. W., Kleeman, M., Krzyzanowski, M., Kunzli, N., Liousse, C., Lung, S. C., Martin, R. V., Poschl, U., Pope III, C. A., Roberts, J. M., Russell, A. G., and Wiedinmyer, C.: What we breathe impacts our health: Improving understanding of the link between air pollution and health, Environ. Sci. Technol., 50, 4895-4904, https://doi.org/10.1021/acs.est.5b03827, 2016.

WHO: (World Health Organization) Air quality guidelines - global update 2005, available at: http://www.who.int/phe/health_topics/ outdoorair/outdoorair_aqg/en/ (last access: 7 July 2017), 2005. 
Wu, Q. R., Wang, S. X., Zhang, L., Song, J. X., Yang, H., and Meng, Y.: Update of mercury emissions from China's primary zinc, lead and copper smelters, 2000-2010, Atmos. Chem. Phys., 12, 11153-11163, https://doi.org/10.5194/acp-12-111532012, 2012.

Yanca, C. A., Barth, D. C., Petterson, K. A., Nakanishi, M. P., Cooper, J. A., Johnsen, B. E., Lambert, R. H., and Bivins, D. G.: Validation of three new methods for determination of metal emissions using a modified Environmental Protection Agency Method 301, J. Air Waste Manage. Assoc., 56, 1733-1742, https://doi.org/10.1080/10473289.2006.10464578, 2006.

Yu, S.: Water spray geoengineering to clean air pollution for mitigating haze in China's cities, Environ. Chem. Lett., 12, 109-116, https://doi.org/10.1007/s10311-013-0444-0, 2014.
Zhang, X., Hecobian, A., Zheng, M., Frank, N. H., and Weber, R. J.: Biomass burning impact on $\mathrm{PM}_{2.5}$ over the southeastern US during 2007: integrating chemically speciated FRM filter measurements, MODIS fire counts and PMF analysis, Atmos. Chem. Phys., 10, 6839-6853, https://doi.org/10.5194/acp10-6839-2010, 2010.

Zhao, M., Zhang, Y., Ma, W., Fu, Q., Yang, X., Li, C., Zhou, B., Yu, Q., and Chen, L.: Characteristics and ship traffic source identification of air pollutants in China's largest port, Atmos. Environ., 64, 277-286, https://doi.org/10.1016/j.atmosenv.2012.10.007, 2013.

Zhen, L., Li, M., Hu, Z., Lv, W., and Zhao, X.: The effects of emission control area regulations on cruise shipping, Transport. Res. D-Tr. E., 62, 47-63, https://doi.org/10.1016/j.trd.2018.02.005, 2018.

Zheng, J., Tan, M., Shibata, Y., Tanaka, A., Li, Y., Zhang, G., Zhang, Y., and Shan, Z.: Characteristics of lead isotope ratios and elemental concentrations in $\mathrm{PM}_{10}$ fraction of airborne particulate matter in Shanghai after the phaseout of leaded gasoline, Atmos. Environ., 38, 1191-1200, https://doi.org/10.1016/j.atmosenv.2003.11.004, 2004. 